\title{
Regulation of Monocytes/Macrophages by the Renin-Angiotensin System in Diabetic Nephropathy: State of the Art and Results of a Pilot Study
}

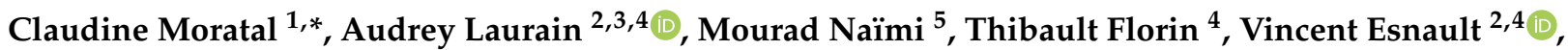 \\ Jaap G. Neels ${ }^{1} @$, Nicolas Chevalier ${ }^{6}$, Giulia Chinetti ${ }^{6}$ and Guillaume Favre ${ }^{2,3,4}(\mathbb{D}$ \\ check for \\ 1 Université Côte d'Azur, INSERM, C3M, 06204 Nice, France; jaap.neels@univ-cotedazur.fr \\ 2 Faculty of Medicine, Côte d'Azur University, 06107 Nice, France; laurain.a@chu-nice.fr (A.L.); \\ esnault.v@chu-nice.fr (V.E.); favre.g@chu-nice.fr (G.F.) \\ 3 Centre National de la Recherche Scientifique, UMR 7073, Laboratory of Physiology and Molecular \\ Medicine (LP2M), 06107 Nice, France \\ 4 Nephrology, Dialysis and Transplantation Department, University Hospital, 06002 Nice, France; \\ florin.t@chu-nice.fr \\ 5 Université Côte d'Azur, CHU, 06000 Nice, France; naimi.m@chu-nice.fr \\ 6 Université Côte d'Azur, CHU, INSERM, C3M, 06000 Nice, France; chevalier.n@chu-nice.fr (N.C.); \\ Giulia.CHINETTI@univ-cotedazur.fr (G.C.) \\ * Correspondence: cmoratal@unice.fr
} updates

Citation: Moratal, C.; Laurain, A.; Naïmi, M.; Florin, T.; Esnault, V.; Neels, J.G.; Chevalier, N.; Chinetti, G.; Favre, G. Regulation of Monocytes/Macrophages by the Renin-Angiotensin System in Diabetic Nephropathy: State of the Art and Results of a Pilot Study. Int. J. Mol. Sci. 2021, 22, 6009. https:// doi.org/10.3390/ijms22116009

\section{Academic Editors:}

Michaela Adamcova, Fedor Simko and Ludovit Paulis

Received: 10 March 2021

Accepted: 28 May 2021

Published: 2 June 2021

Publisher's Note: MDPI stays neutral with regard to jurisdictional claims in published maps and institutional affiliations.

Copyright: (c) 2021 by the authors. Licensee MDPI, Basel, Switzerland. This article is an open access article distributed under the terms and conditions of the Creative Commons Attribution (CC BY) license (https:// creativecommons.org/licenses/by/ $4.0 /)$.

\begin{abstract}
Diabetic nephropathy (DN) is characterized by albuminuria, loss of renal function, renal fibrosis and infiltration of macrophages originating from peripheral monocytes inside kidneys. DN is also associated with intrarenal overactivation of the renin-angiotensin system (RAS), an enzymatic cascade which is expressed and controlled at the cell and/or tissue levels. All members of the RAS are present in the kidneys and most of them are also expressed in monocytes/macrophages. This review focuses on the control of monocyte recruitment and the modulation of macrophage polarization by the RAS in the context of DN. The local RAS favors the adhesion of monocytes on renal endothelial cells and increases the production of monocyte chemotactic protein-1 and of osteopontin in tubular cells, driving monocytes into the kidneys. There, proinflammatory cytokines and the RAS promote the differentiation of macrophages into the M1 proinflammatory phenotype, largely contributing to renal lesions of DN. Finally, resolution of the inflammatory process is associated with a phenotype switch of macrophages into the M2 anti-inflammatory subset, which protects against DN. The pharmacologic interruption of the RAS reduces albuminuria, improves the trajectory of the renal function, decreases macrophage infiltration in the kidneys and promotes the switch of the macrophage phenotype from M1 to M2.
\end{abstract}

Keywords: macrophages; renin-angiotensin system; diabetic nephropathy

\section{Introduction}

Sustained fasting glycemia over $7.00 \mathrm{mmol} / \mathrm{L}$ is the definition of diabetes mellitus that may result either from insulin deficiency following insulin resistance in type 2 diabetes (T2D) or from insulin deficiency caused by destruction of beta cells in the pancreatic islets in type 1 diabetes (T1D). Diabetic nephropathy (DN) is the leading cause of end-stage renal disease in the world and is considered an inflammatory disease. This is illustrated by renal infiltration of monocytes originating from the bone marrow and by lower occurrence of kidney lesions observed in experimental studies targeting disruption of monocytes/macrophages [1]. The inflammatory process is initiated by poor glycemic control and/or high level of albuminuria. Peripheral monocytes enter the kidneys, differentiate into macrophages of diverse phenotypes and their abundancy parallels the renal fibrosis, which negatively correlates with the renal function [2]. 
Diabetic nephropathy is also characterized by activation of the renin-angiotensin system (RAS). The RAS is an enzymatic cascade which produces various types of angiotensins [3]. At the systemic level, the RAS regulates the arterial tone and the extracellular fluid volume. At the tissue level, the differential expression of the key enzymes and of their receptors may lead to various effects, even to opposite effects [4]. There is a complete RAS intrinsic to the kidneys $[5,6]$ and some components of the RAS intrinsic to the monocyte/macrophage system $[7,8]$. They both have a dual role. In DN, activated components of the RAS turn out to be harmful: they are proinflammatory, profibrotic and they enhance the oxidative stress. The bulk of experimental data shows that stimulation of the antagonistic components of the RAS may protect against the lesions of DN. In humans, however, only the pharmacological interruptions of the deleterious compounds are efficient $[9,10]$. In reality, blockade of the activated harmful RAS components in humans decreases blood pressure and albuminuria and improves the trajectory of the renal function [11]. Here, we review the interactions of the kidneys and the monocyte/macrophage system through the RAS in DN in order to highlight the potential treatments available.

\section{Pathophysiology of DN}

\subsection{Renal Function Consequences of DN}

The onset of $\mathrm{DN}$ is characterized by the increase in renal size and weight because the tubules and the glomeruli develop hyperplasia and hypertrophy [12]. As a result, the proximal tubule reabsorbs a higher amount of sodium via sodium-glucose cotransporter type 2 (SGLT2), leading to afferent arteriole vasodilation and sustained glomerular hyperfiltration. Glomerular hyperfiltration favors hypertension, renal function loss and albuminuria $[13,14]$. Albuminuria is measured by the urinary albumin over creatinine ratio (UACR). Microalbuminuria is defined by the UACR from $20 \mathrm{mg} / \mathrm{g}$ to $300 \mathrm{mg} / \mathrm{g}$ in women and from $30 \mathrm{mg} / \mathrm{g}$ to $300 \mathrm{mg} / \mathrm{g}$ in men, and macroalbuminuria is defined by the UACR over $300 \mathrm{mg} / \mathrm{g}$. The renal function is characterized by the glomerular filtration rate (GFR), which is used to define hyperfiltration (GFR $>120 \mathrm{~mL} / \mathrm{min} / 1.73 \mathrm{~m}^{2}$ ), normal renal function $\left(60 \leq\right.$ GFR $\left.\leq 120 \mathrm{~mL} / \mathrm{min} / 1.73 \mathrm{~m}^{2}\right)$ or renal insufficiency $\left(\mathrm{GFR}<60 \mathrm{~mL} / \mathrm{min} / 1.73 \mathrm{~m}^{2}\right)$ of varying severity until end-stage renal disease (GFR $<15 \mathrm{~mL} / \mathrm{min} / 1.73 \mathrm{~m}^{2}$ ).

In contrast with the description of the five successive stages of $\mathrm{DN}$, which prevailed between the 1980s and the last decade [15], it is now established that microalbuminuria does not necessarily develop into macroalbuminuria and that renal insufficiency occurs and progresses together with micro- or macroalbuminuria. The pathological classification of DN is based on the grade of glomerulosclerosis. The extracellular matrix expansion in the glomeruli starts with the thickening of the basement membrane to end up in the nodular depots inside the glomerular tufts called Kimmerstiel-Wilson nodules, and the pathological classification accepts four classes [16]. However, glomerulosclerosis does not indicate the severity of renal insufficiency, which is only revealed by interstitial fibrosis. It is firmly established that interstitial fibrosis correlates negatively with the renal function in all kinds of nephropathy and most particularly in DN [17-19]. The development of renal fibrosis is a complex and multistep process which results from an imbalance between the production and the degradation of the extracellular matrix [20].

\subsection{Cellular Consequences of Hyperglycemia}

Hyperglycemia per se is responsible for kidney cell injuries in proximal tubular cells, mesangial cells and endothelial cells. These cells express glucose transporter 2 (GLUT2) and, as a consequence, they experience a high cytoplasmic glucose level due to diffusion from blood down its chemical gradient. Consequently, the glycolytic pathways provide excess energy supply to the mitochondrial respiratory chain and electrons are transferred to oxygen molecules $\left(\mathrm{O}_{2}\right)$ rather than to mitochondrial transport molecules (cytochromes), resulting in the overproduction of reactive oxygen species (ROS). In turn, ROS reduce glycolysis by inhibiting GAPDH and accumulation of glucose metabolites activates the polyol- and the PKC pathways, thereby favoring production of advanced glycation end- 
products (AGE) and of $\mathrm{N}$-acetyl glucosamine, leading to renal cell injuries [21]. In addition, increased intraglomerular pressure due to glomerular hyperfiltration promotes albuminuria. Renal production of ROS, glucose metabolites and glycated albumin in urine promote inflammation. Indeed, the release of cytokines and danger-associated molecular patterns (DAMPs) [22] and the production of monocyte chemoattractant protein-1 (MCP-1) in renal cells [23] attract monocytes from the blood into the kidneys; these monocytes then differentiate into macrophages. The presence of macrophages in the kidneys is positively correlated with renal fibrosis in humans [24-26].

\subsection{Experimental In Vivo Models of DN}

Hyperglycemia that initiates DN development can be differentially induced according to diabetic animal models. Several experimental models of DN exist, some mimicking the pathological situations observed in T1D and other reconstituting the context of T2D. Indeed, some mice are hyperglycemic due to insulin deficiency, thus recalling the mechanism of T1D. This happens after streptozotocin (STZ) administration that destroys beta cells, mutation of the insulin 2 gene that causes abnormal folding of the protein, resulting in beta cell destruction (AKITA mice), or by genetically driven overproduction of calmodulin in beta cells responsible for beta cell destruction (OVE26 mice). Hyperglycemia may also result from insulin resistance. Mutations in the leptin receptor gene $(\mathrm{db} / \mathrm{db}$ mice, Zucker diabetic fatty (ZDF) rats and Wistar fatty rats) or in the leptin gene (ob/ob mice) or the overexpression of neuropeptide $\mathrm{Y}$ in the hypothalamus in Otsuka Long-Evans Tokushima fatty (OLETF) rats lead to hyperphagia, obesity and insulin resistance, thus mimicking the pathophysiology of T2D [27,28]. STZ treatment can also mimic the metabolic characteristics of T2D in humans when used in combination with a high-fat diet [29] and neonatal administration of STZ is a well-established animal model for T2D in rats [30].

The Animal Models of Diabetic Complications Consortium (AMDCC) defines the key criteria validating a progressive rodent model of DN (https://www.diacomp.org/ shared / document.aspx?id=25\&docType=Protocol accessed on 28 May 2021): at least 50\% decline in GFR, greater than 10-fold increase in albuminuria as compared with appropriate controls and fibrosis measured by mesangial sclerosis, arterial hyalinosis, thickening of the glomerular basement membrane to more than $50 \%$ or tubulointerstitial fibrosis [16,31]. Nevertheless, no animal model of DN exhibits all these criteria. For that reason, in the present review, the described models used are specified and not simply referred to as a T1D or T2D model. As in humans, DN in rodents can be accelerated by concomitant induction of hypertension through the knockout of the endothelial nitric oxide synthase (eNOS) gene [32] or through the knock-in of the mouse Ren-2 gene in transgenic (mREN-2)27 rats called Ren-2 rats [33].

\section{Roles of Monocytes/Macrophages in DN}

Tissue-resident macrophages are mostly derived directly from fetal liver or yolk sac during embryogenesis and are described as microglia in the brain, Kupffer cells in the liver and interstitial macrophages in the kidneys. These macrophages are long-lived, do not migrate and are maintained by self-renewal [34]. In contrast, following infection/injury, circulating monocytes originating from the bone marrow migrate into the injured tissue where they differentiate into macrophages $[35,36]$. These macrophages are called monocyte-derived macrophages or monocyte-derived tissue-resident macrophages and they significantly contribute to diabetes-induced kidney injury. Actually, diverse experimental strategies aimed at impairing monocyte recruitment into the kidneys or reducing their absolute number in the body decrease renal fibrosis. For instance, tubulin inhibition by colchicine alters diapedesis and significantly reduces macrophages and interstitial fibrosis in the kidneys of STZ-treated rats [37]. Furthermore, the whole-body depletion of monocytes/macrophages obtained by intraperitoneal injection of clodronate liposomes [38] or by the administration of diphtheria toxin in the CD11b-DTR model [36] reduces macrophage infiltration and renal fibrosis in STZ-treated mice. CD11b-DTR (diphtheria toxin receptor) 
mice express the transgene insert that contains a fusion product involving DTR and the green fluorescent protein under the control of the human CD11b promoter [39]. Diphtheria toxin poorly links to murine DTR conferring toxin sensitivity to human DTR specifically expressed in mouse macrophages. These data clearly indicate that renal accumulation of macrophages is a critical factor in the development of DN (Table 1).

Table 1. Renal effects of strategies targeting monocyte/macrophage recruitment and polarization in animal models of DN.

\begin{tabular}{|c|c|c|c|c|}
\hline Diabetic Models & Strategies & $\begin{array}{l}\text { Effects on Macrophage } \\
\text { Recruitment and Polarization } \\
\text { in Kidneys }\end{array}$ & Renal Effects & Ref. \\
\hline \multirow{17}{*}{ STZ-treated mice } & $\begin{array}{l}\text { induced depletion of } \\
\text { macrophages with } \\
\text { diphtheria toxin }\end{array}$ & \multirow{4}{*}{$\downarrow$ macrophage infiltration } & $\begin{array}{c}\downarrow \text { glomerulosclerosis and } \\
\text { albuminuria }\end{array}$ & [36] \\
\hline & clodronate liposomes & & $\begin{array}{l}\downarrow \text { UACR, renal fibrosis and } \\
\text { glomerulosclerosis }\end{array}$ & [38] \\
\hline & $M c p-1^{-/-}$ & & $\begin{array}{c}\downarrow \text { albuminuria and } \\
\text { renal fibrosis }\end{array}$ & [40] \\
\hline & $\begin{array}{c}\text { propagermanium } \\
\text { (CCR2 antagonist) } \\
\text { administration or } \\
M c p-1^{-/-}\end{array}$ & & $\begin{array}{l}\downarrow \text { glomerulosclerosis and } \\
\text { collagen deposition }\end{array}$ & [41] \\
\hline & $C \times 3 c r 1^{-/-}$ & $\begin{array}{c}\downarrow \text { macrophage infiltration and } \\
\text { MCP-1 renal expression }\end{array}$ & $\begin{array}{l}\downarrow \text { glomerulosclerosis and } \\
\text { interstitial fibrosis }\end{array}$ & [42] \\
\hline & $\begin{array}{l}\text { G31P (antagonist } \\
\text { of CXCL8) }\end{array}$ & $\begin{array}{c}\downarrow \text { macrophage } \\
\text { marker expression }\end{array}$ & $\begin{array}{c}\downarrow \text { glomerulosclerosis and } \\
\text { renal fibrosis }\end{array}$ & [43] \\
\hline & IL-17A & $\begin{array}{c}\downarrow \text { urinary MCP- } 1 \text { level and } \\
\text { macrophage renal infiltration }\end{array}$ & $\downarrow$ glomerulosclerosis & [44] \\
\hline & $I l-17^{-/-}$ & $\downarrow$ macrophage infiltration & $\begin{array}{l}\downarrow \text { albuminuria and } \\
\text { glomerulosclerosis }\end{array}$ & [45] \\
\hline & $\begin{array}{l}\text { IL-17A monoclonal } \\
\text { antibodies }\end{array}$ & $\begin{array}{c}\text { no effect on } \\
\text { macrophage infiltration }\end{array}$ & $\downarrow$ glomerulosclerosis & [45] \\
\hline & Icam-1-/- & $\downarrow$ macrophage infiltration & $\begin{array}{c}\downarrow \text { glomerulosclerosis, } \downarrow \\
\text { albuminuria and glomerular } \\
\text { collagen IV deposition }\end{array}$ & [46] \\
\hline & $\begin{array}{l}\text { endothelial heparan } \\
\text { sulfate deficiency }\end{array}$ & $\downarrow$ macrophage infiltration & $\begin{array}{c}\downarrow \text { glomerulosclerosis and } \\
\text { interstitial renal fibrosis }\end{array}$ & [47] \\
\hline & recombinant pentraxin 3 & $\begin{array}{c}\downarrow \mathrm{M} 1 \text { and } \uparrow \mathrm{M} 2 \\
\text { macrophage infiltration }\end{array}$ & $\begin{array}{c}\text { preserved slit } \\
\text { diaphragm proteins }\end{array}$ & [48] \\
\hline & $\begin{array}{l}\text { pentraxin } 3 \text { monoclonal } \\
\text { antibodies }\end{array}$ & $\begin{array}{l}\uparrow \mathrm{M} 1 \text { and } \downarrow \mathrm{M} 2 \\
\text { macrophage infiltration }\end{array}$ & $\begin{array}{c}\text { altered slit } \\
\text { diaphragm proteins }\end{array}$ & [48] \\
\hline & $\begin{array}{l}\text { administration of } \\
\text { IL-4-/IL-13-treated M2 } \\
\text { macrophages }\end{array}$ & $\uparrow \mathrm{M} 2$ macrophage infiltration & $\begin{array}{l}\downarrow \text { interstitial fibrosis and } \\
\text { glomerulosclerosis }\end{array}$ & [49] \\
\hline & mesenchymal stem cells & $\begin{array}{c}\downarrow \mathrm{M} 1 \text { and } \uparrow \mathrm{M} 2 \text { macrophage } \\
\text { infiltration }\end{array}$ & $\begin{array}{l}\downarrow \text { UACR, renal fibrosis and } \\
\text { glomerulosclerosis }\end{array}$ & [38] \\
\hline & $\operatorname{Tl} 2^{-/-}$ & $\begin{array}{c}\downarrow \mathrm{M} 1 \text { macrophage infiltration, } \\
\downarrow \\
\downarrow \text { serum and renal } \\
\text { MCP-1 levels }\end{array}$ & $\begin{array}{l}\text { preserved slit diaphragm } \\
\text { proteins, normalized } \\
\text { renal weight }\end{array}$ & [50] \\
\hline & $\begin{array}{c}\text { cyclooxygenase- } 2 \\
\text { deletion in hematopoietic } \\
\text { stem cells }\end{array}$ & $\begin{array}{c}\uparrow \text { macrophage infiltration, } \downarrow \\
\text { M2 macrophage infiltration } \\
\text { and marker expression, } \uparrow \text { renal } \\
\text { MCP- } 1 \text { expression }\end{array}$ & $\begin{array}{c}\downarrow \text { deposition of collagen in } \\
\text { glomeruli and of } \alpha \text {-SMA } \\
\text { in interstitium }\end{array}$ & [51] \\
\hline $\begin{array}{l}\text { STZ-treated mice } \\
\text { deficient for Nos3 }\end{array}$ & CCR2 antagonists & $\downarrow$ macrophage infiltration & $\begin{array}{l}\downarrow \text { UACR and collagen IV } \\
\text { deposition in glomeruli }\end{array}$ & [52] \\
\hline
\end{tabular}


Table 1. Cont.

\begin{tabular}{|c|c|c|c|c|}
\hline Diabetic Models & Strategies & $\begin{array}{l}\text { Effects on Macrophage } \\
\text { Recruitment and Polarization } \\
\text { in Kidneys }\end{array}$ & Renal Effects & Ref. \\
\hline \multirow{5}{*}{ STZ-treated rats } & colchicine & $\begin{array}{c}\downarrow \text { macrophage infiltration, } \downarrow \\
\text { MCP-1 and ICAM-1 renal } \\
\text { expression }\end{array}$ & $\begin{array}{c}\downarrow \text { albuminuria and ECM } \\
\text { accumulation }\end{array}$ & [37] \\
\hline & $\begin{array}{l}\text { ICAM-1 monoclonal } \\
\text { antibodies }\end{array}$ & $\downarrow$ macrophage infiltration & $\begin{array}{l}\text { correction of glomerular } \\
\text { hyperfiltration }\end{array}$ & [53] \\
\hline & calcitriol & $\begin{array}{c}\downarrow \mathrm{M} 1 \text { and } \uparrow \mathrm{M} 2 \text { macrophage } \\
\text { marker expression }\end{array}$ & \multirow{2}{*}{$\downarrow$ glomerulosclerosis } & [54] \\
\hline & $25-\mathrm{OH}$ vitamin $\mathrm{D}$ & $\downarrow$ macrophage infiltration & & [55] \\
\hline & hemin & $\begin{array}{c}\downarrow \text { renal urinary MCP-1 levels, } \downarrow \\
\text { renal macrophage infiltration, } \\
\downarrow \mathrm{M} 1 \text { and } \uparrow \mathrm{M} 2 \text { macrophage } \\
\text { marker expression }\end{array}$ & $\begin{array}{l}\text { prevented kidney } \\
\text { overweight and } \\
\text { restored GFR }\end{array}$ & [56] \\
\hline \multirow{6}{*}{$\mathrm{db} / \mathrm{db}$ mice } & $\begin{array}{l}\text { CCL2 antagonizing } \\
\text { L-RNA aptamer }\end{array}$ & \multirow[b]{2}{*}{$\downarrow$ macrophage infiltration } & $\downarrow$ glomerulosclerosis & [57] \\
\hline & $M c p-1^{-/-}$ & & $\begin{array}{c}\downarrow \text { interstitial and glomerular } \\
\text { collagen IV deposition, } \downarrow \\
\text { tubular atrophy }\end{array}$ & [40] \\
\hline & IL-17A & $\downarrow$ urinary MCP-1 level & $\downarrow$ glomerulosclerosis & [44] \\
\hline & Icam-1-/- & $\downarrow$ macrophage infiltration & $\begin{array}{l}\downarrow \text { glomerulosclerosis, renal } \\
\text { fibrosis and albuminuria }\end{array}$ & [58] \\
\hline & tectorigenin & $\begin{array}{c}\downarrow \text { macrophage infiltration, } \downarrow \\
\text { M1 and } \uparrow \text { M2 macrophage } \\
\text { marker expression }\end{array}$ & $\begin{array}{c}\text { preserved slit diaphragm } \\
\text { proteins, } \downarrow \\
\text { glomerulosclerosis }\end{array}$ & [59] \\
\hline & $\begin{array}{l}c-f m s \text { monoclonal } \\
\text { antibodies }\end{array}$ & $\begin{array}{c}\downarrow \text { macrophage infiltration, } \downarrow \\
\text { urine excretion of MCP-1 }\end{array}$ & $\begin{array}{c}\downarrow \text { renal weight without } \\
\text { normalization, } \downarrow \\
\text { hyperfiltration and } \\
\text { interstitial collagen } \\
\text { deposition }\end{array}$ & [60] \\
\hline \multirow[b]{2}{*}{ Ins2Akita mutant mice } & IL-17A & $\downarrow$ urinary MCP-1 level & $\downarrow$ glomerulosclerosis & [44] \\
\hline & AMPWAP & $\begin{array}{c}\downarrow \mathrm{M} 1 \text { and } \uparrow \mathrm{M} 2 \text { macrophage } \\
\text { marker expression }\end{array}$ & $\begin{array}{l}\downarrow \text { glomerulosclerosis } \\
\text { and albuminuria }\end{array}$ & [44] \\
\hline $\begin{array}{l}\text { Zucker diabetic } \\
\text { fatty rats }\end{array}$ & hemin & $\begin{array}{c}\downarrow \text { M1 macrophage infiltration } \\
\text { and M1 marker expression, } \uparrow \\
\text { M2 macrophage } \\
\text { marker expression }\end{array}$ & $\begin{array}{c}\text { restored GFR, } \\
\downarrow \text { collagen deposition }\end{array}$ & [61] \\
\hline
\end{tabular}

Abbreviations: UACR, urinary albumin-to-creatinine ratio; $\alpha$-SMA, $\alpha$-smooth muscle actin; AMWAP, activated microglia/macrophage whey acidic protein; CCR2, C-C chemokine receptor type 2; CXCL8, C-X-C motif chemokine ligand 8; CX3cr1, CX3C chemokine receptor 3; ECM, extracellular matrix; GFR, glomerular filtration rate; ICAM-1, intracellular adhesion molecule-1; L-RNA, L-ribonucleic acid; MCP-1, monocyte chemoattractant protein-1; Nos3, nitric oxide synthase 3; STZ, streptozotocin; TLR2, toll-like receptor 2.

\subsection{Monocyte Recruitment in DN}

Monocytes cross the endothelium layer by diapedesis, a multistep process including capture, rolling, slow rolling, arrest, adhesion strengthening, lateral locomotion and monocyte transmigration. Diapedesis involves interactions between endothelial cells expressing ICAM-1 (intracellular adhesion molecule-1) and VCAM-1 (vascular cell adhesion molecule-1) and monocyte ligands such as selectins [62].

In T2D patients, serum ICAM-1 concentration is higher in the presence of microalbuminuria than in patients without microalbuminuria [63]. In the kidneys of $\mathrm{db} / \mathrm{db}$ mice [58] or ZDF rats [64], ICAM-1 expression is higher than in their non-diabetic counterparts. Icam- $1^{-/-} \mathrm{db} / \mathrm{db}$ mice [58] or Icam-1 ${ }^{-/-}$STZ-treated mice [46] show a reduced renal macrophage count (Table 1). Further, neutralization of ICAM-1 with a specific monoclonal antibody in STZ-treated mice reduces the number of glomerular macrophages [53]. VCAM1 is significantly more abundant in the urinary proteome of T2D patients as compared to 
people without diabetes [65], but the effects of VCAM-1 depletion on the renal macrophage infiltration have not been studied to our knowledge.

Immunohistochemistry analysis of kidney biopsies in humans shows that expression of E- and L-selectins is more abundant in renal vessels from the patients with DN than in vessels from the patients with other kinds of nephropathy. The presence of E-selectin in the peritubular capillaries is positively correlated with the renal macrophage count [66]. In STZ-treated mice, the reduced interaction of L-selectin with its ligands on endothelial cells due to heparan sulfate deficiency significantly reduces the renal macrophage count [47].

The recruitment of monocytes is mainly controlled by chemokines such as MCP-1, also named $\mathrm{C}-\mathrm{C}$ motif chemokine ligand 2 (CCL2), that binds to $\mathrm{C}-\mathrm{C}$ chemokine receptor type 2 (CCR2) on the surface of monocytes [67]. Indeed, MCP-1 deletion [40] or blockade by administration of a CCL2-antagonizing L-RNA aptamer [57] or of a CCR2 antagonist [41] decreases macrophage renal infiltration and consequently decreases kidney injury in STZtreated mice or in $\mathrm{db} / \mathrm{db}$ mice (Table 1). The synthesis of MCP-1 is under the control of the nuclear factor kappa B (NF kappa B), a transcription factor whose activity is stimulated by tubular reabsorption of excess filtered albumin. NF kappa B controls MCP-1 production in human tubular cells [68] and in the renal cells from uremic rats [69]. In addition, glycated albumin stimulates NF kappa B activity in mesangial cells [70]. In humans, urinary MCP-1 is positively correlated with albuminuria levels [71-73] and hyperglycemia according to the level of glycated proteins [70].

Renal infiltration of monocytes also depends on the binding of monocytes to molecules from the extracellular matrix. The renal expression of osteopontin (OPN), a phosphoglycoprotein adhesion molecule, is upregulated in DN in humans, in STZ-treated mice, in $\mathrm{db} / \mathrm{db}$ mice [74] and in OLETF rats [75]. OPN binds to CD44 on monocytes and promotes monocyte invasion in the kidneys [76]. In STZ-treated hypertensive Ren-2 rats, OPN is overexpressed in mesangial cells [77], podocytes [78], endothelial cells [79] and in tubular cells in association with extensive macrophage accumulation in the kidneys [80,81]. Furthermore, OPN deletion in $\mathrm{db} / \mathrm{db}$ mice, Akita mice or STZ-treated mice decreases the lesions of DN, indicating that OPN-dependent monocyte recruitment plays an important role in $\mathrm{DN}$ [82]. In vitro treatment of human proximal tubular cells by glucose enhances OPN expression, an effect involving toll-like receptor-4 (TLR4) activation [83], phosphatidylinositol 3-kinase- [84] and the beta isoform of protein kinase C [81]-dependent pathways.

Fractalkine (CX3CL1) also drives monocytes into the kidneys since CX3CL1 and its receptor (CX3CR1) are overexpressed in the kidneys of STZ-treated rats, and some CX3CR $1^{+}$cells are monocytes/macrophages [85]. Presence of renal macrophages decreases in $\mathrm{Cx}_{3} \mathrm{Cr}^{-/-}$mice treated with STZ, indicating that their number depends on the CX3CL1/CX3CR1 interaction [42]. In vitro experiments show that CX3CL1 originates from human mesangial cells exposed to AGE [86]. In addition to MCP-1 and CX3CL1, the importance of other chemokines or cytokines in the recruitment of monocytes, such as CXCL8 [43] and IL-17A [44,45], is becoming apparent.

\subsection{Macrophage Polarization and Plasticity in DN}

Once in tissues, infiltrating monocytes differentiate into macrophages according to microenvironmental signals and molecules [87]. Macrophage polarization can be induced in vitro by distinct stimuli and different functional phenotypes are identified based on the expression of several markers (cytokines, growth factors, chemokine receptors and surface antigens) [88,89].

Very schematically, two classes of macrophages are described in in vitro studies. Classically activated (M1) macrophages result from the exposure of monocytes to TH1 cytokines, such as interferon- $\gamma$ (IFN $\gamma$ ), interleukin (IL) $1 \beta$ and tumor necrosis factor- $\alpha$ (TNF- $\alpha$ ) or to lipopolysaccharides (LPS). M1 macrophages display a high capacity to present antigens and produce high levels of proinflammatory cytokines, such as IL- $1 \beta$, IL-6, IL-12 and TNF- $\alpha$, but a low level of IL-10. Chronic M1 macrophage activation can, therefore, mediate ROS-induced tissue damage and impair wound healing. To protect 
against such tissue damage, the inflammatory response is spatially and temporally counterbalanced by regulatory mechanisms driven by alternatively activated (M2) macrophages. Indeed, macrophages are plastic cells because they can switch from an active M1 to M2 and vice versa upon specific signals. Alternatively activated (M2) macrophages produce anti-inflammatory cytokines such as IL-10, growth factors and profibrotic factors like transforming growth factor- $\beta$ (TGF- $\beta$ ) involved in the wound healing and fibrosis process. In humans, M2 macrophages express specific markers including CD163, CD206, CD200R, alternative macrophage activation-associated CC-chemokine 1 (AMAC1) [90] and coagulation factor XIII A1 (FXIIIA1). In in vitro experiments, the M2 phenotype can be induced by several combinations of stimuli: TH2 cytokines IL-4 or IL-13 (M2a), immune complexes in combination with IL-1 $\beta$ or LPS (M2b), IL-10 or glucocorticoids (M2c) or by costimulation with TLR ligands and A2 adenosine receptor agonists or by IL-6 (M2d) [91].

M1/M2 classification of macrophages is a simplistic overview of macrophage polarization and functions and does not represent the macrophage phenotypes observed in vivo since the tissue microenvironment is more complex with the simultaneous presence of several stimuli. For instance, M2a, M2b, M2c and M2d are not described in DN, and for that reason, we use here the nomenclature of M1 and M2 macrophages without distinction between the different subsets of the M2 phenotype.

The modulation of macrophage polarization toward the M2 phenotype is associated with a decrease in renal fibrosis as illustrated by several experimental studies (Table 1). Indeed, transfusion of IL-4/IL-13-polarized M2 macrophages in STZ-treated mice protects against tubular atrophy and interstitial fibrosis [49]. Conversely, deletion of cyclooxygenase2 in STZ-treated mice increases renal M1 macrophages and renal fibrosis [51]. Cellular interactions between macrophages and mesenchymal stem cells increase the ratio of M2/M1 macrophages in the kidneys from STZ-treated mice [38]. Several translational research projects are ongoing in humans to assess the efficacy and safety of intraarterially delivered mesenchymal stem cells/stromal cells from the adipose tissue (NCT03840343) or from the umbilical cord (NCT04562025, NCT04216849) in patients with DN. Low doses of IL17A reduce the renal macrophage count, IL- 6 and TNF- $\alpha$ proteins in urine from $\mathrm{db} / \mathrm{db}$ mice [44]. Knockout of TLR-2 represses the kidney expression of IL-1 $\beta$, IL-6, MCP-1, which are M1 macrophage-produced cytokines, in the kidneys of STZ-treated mice [50]. Pentraxin 3 decreases the number of M1 macrophages in the kidneys from STZ-treated mice and promotes the switch toward M2 macrophages, as shown by the induction of arginase 1 and CD206 and by the reduction of inducible nitric oxide synthase (iNOS) and CD16/32 proteins [48]. Hemin, an inducer of the heme oxygenase system, selectively modulates macrophage polarization toward the anti-inflammatory M2 macrophages in the kidneys of ZDF rats or STZ-treated rats [56,61]. In all the aforementioned studies, experimentally induced diabetes is associated with proinflammatory M1 macrophage infiltration in the kidneys. The switch toward the M2 phenotype is associated with the resolution of inflammation and with reduced renal fibrosis, lower albuminuria and/or better renal function.

In humans, the lack of longitudinal studies in the same subjects limits our understanding of macrophage plasticity in DN. In transversal studies, there is a predominance of the M2 phenotype in high pathological grades of DN but the severity of renal fibrosis very likely correlates with the duration and/or with the severity of the proinflammatory phase, which occurred before and was not assessed in these studies. For instance, in an autopsy-based study, the grade of renal fibrosis positively correlated with $\mathrm{CD} 163^{+} \mathrm{M} 2$ macrophages [26] and in a biopsy-based study, the renal M1 macrophage count positively correlated with low fibrosis, whereas the renal M2 macrophage infiltration predominated in patients with high fibrosis [25]. 


\section{Regulation of Monocytes/Macrophages by the RAS in DN}

\subsection{Brief Description of the RAS in DN}

There is the systemic RAS, which regulates extracellular fluid volume and arterial pressure. It contrasts with a local RAS, which is expressed at the tissue level where it warrants non-hemodynamic functions [92]. RAS is an enzymatic cascade (Figure 1). The first and limiting step of the enzymatic cascade is the synthesis of angiotensin I (Ang-I) obtained by cutting off the N-terminal part of angiotensinogen (Agt) by renin. Renin is synthesized as an inactive proenzyme (prorenin) which becomes enzymatically active through either catalytic cutting off the N-terminal propeptide by a convertase, or by a conformational change after its binding to the renin/prorenin receptor (PRR). Besides its enzymatic action, PRR may also trigger intracellular pathways [93]. Ang-I is a tenamino acid protein that gives rise to several angiotensins. Angiotensin-converting enzyme (ACE) is a dicarboxypeptidase that deletes 2 amino acids at the C-terminal end of several angiotensins. From Ang-I, ACE generates an octopeptide, angiotensin II (Ang-II). From angiotensin 1,9 (Ang-(1,9)), ACE generates angiotensin 1,7 (Ang-(1,7)). ACE type 2 (ACE2) is a monocarboxypeptidase that removes one amino acid at the C-terminal part of Ang-I and Ang-II, generating Ang-(1,9) or Ang-(1,7). Neprilysin (NEP) is a tricarboxypeptidase that deletes three amino acids at the C-terminal end of Ang-I and gives rise to Ang-(1,7) [94]. Ang-II can bind to two G-protein-coupled receptors, Ang-II receptor type 1 (AT1R) and Ang-II receptor type 2 (AT2R). Ang-(1,7) acts on its Mas receptor (MASR). Ang-II and Ang- $(1,7)$ are the main hormones of the RAS. However, the role of other angiotensins is emerging and Ang- $(1,9)$ also exerts direct biological effects in the cardiovascular system by binding to AT2R [95]. Activation of AT1R in the glomerular zone of the adrenal glands induces the synthesis of aldosterone, which acts via the mineralocorticoid receptor (MR) and may also act on the glucocorticoid receptor (GR) with a lower affinity [96].

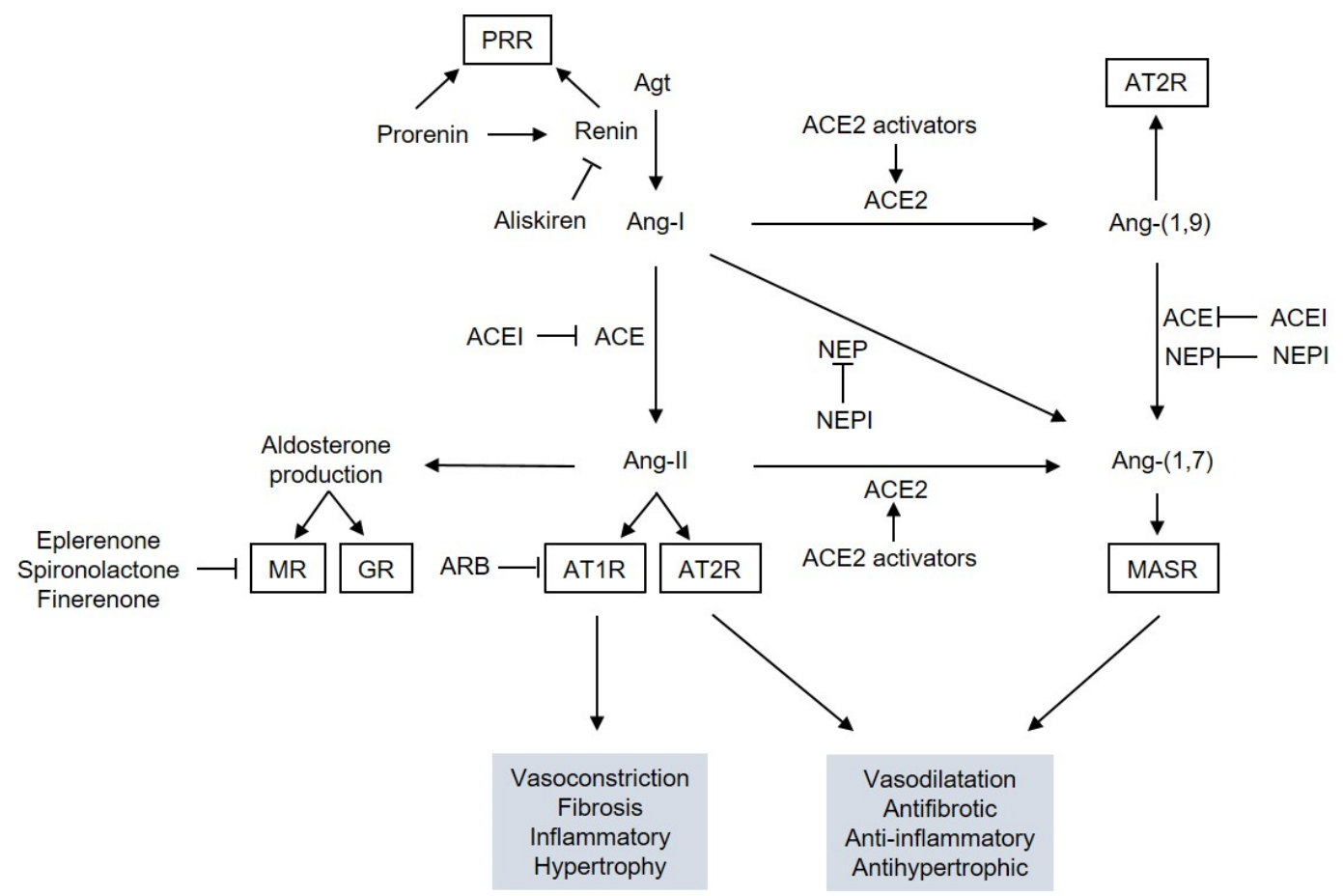

Figure 1. The RAS cascade. Abbreviations: ACE, angiotensin-converting enzyme; ACEI, ACE inhibitor; Agt, angiotensinogen; Ang, angiotensin; ARB, angiotensin receptor blockers; AT1R, Ang-II receptor type 1; AT2R, Ang-II receptor type 2; GR, glucocorticoid receptor; MASR, Mas receptor; MR, mineralocorticoid receptor; NEP, neprilysin; NEPI, NEP inhibitor; PRR, prorenin receptor.

RAS can be interrupted at several levels (Figure 1). Aliskiren is a direct renin inhibitor which blocks the production of all angiotensins [97]. Angiotensin-converting enzyme 
inhibitors (ACEI) repress most of the conversion of Ang-I into Ang-II and of Ang-(1,9) into Ang-(1,7). Angiotensin receptor blockers (ARB) target AT1R [11]. Eplerenone, spironolactone [98] and finerenone [99] are MR antagonists (MRA). Thiorphan belongs to inhibitors of NEP (NEPI) [100]. Finally, diminazene aceturate is an activator of ACE2 [100].

\subsection{Local RAS in the Kidneys}

In the kidneys, all members of the RAS are present and regulate renal functions [92]. There is evidence that hyperglycemia favors the production of Ang-II from tubular and glomerular cells [101]. Globally, the Ang-II, ACE, AT1R, MR axis opposes the actions of the Ang-(1,7), ACE2, MASR, AT2R axis. Briefly, the former axis induces matrix expansion, oxidative stress, vasoconstriction and inflammation, whereas the other axis has antifibrotic, anti-inflammatory and vasodilatory effects. The systemic RAS is low in humans suffering from diabetes mellitus, whereas the RAS intrinsic to the kidneys is activated [102]. This paradox might be accounted for by the repression of systemic renin production from the juxtaglomerular apparatus following increased production of Ang-II in glomerular and tubular cells [101,103]. Actually, there is a 100-fold higher level of Ang-II in the tubular fluid and/or in renal homogenates of several animal models of diabetes than in blood [92].

The activation of the RAS intrinsic to the kidneys is highlighted by the fact that ACEI or ARB are important treatments for patients with DN. They lower hypertension or albuminuria [104-106] and, remarkably, improve the trajectory of the renal function $[107,108]$. Blockade of the terminal step of the deleterious axis of the RAS with finerenone (MRA) in addition to ACEI or ARB is even more efficient to prevent the occurrence of a combined endpoint including the decline of the renal function and the occurrence of cardiovascular events than ACEI or ARB alone in patients with DN [109], whereas comprehensive blockade of the RAS cascade with aliskiren added to ACEI or ARB [110] or ACEI on top of ARB [111] does not improve these outcomes.

\subsection{Local Components of the RAS in Monocytes/Macrophages}

Monocytes/macrophages produce Ang-II through the ACE [112] and Ang-(1,7) from Ang-II via ACE2 [113] and express AT1R [114], AT2R [115], MASR [116] and the MR [117]. Furthermore, macrophages from $l d l^{-/-}$(low-density lipoprotein receptor) mice express Agt and renin in atherosclerotic lesions [118] and PRR was recently detected in human monocyte cell lines, circulating human monocytes and in macrophages infiltrating the kidneys $[119,120]$. Therefore, it is proposed that the RAS produced in an autocrine manner is essential for monocyte-to-macrophage differentiation and for macrophage functions. Moreover, AT1R regulates the differentiation of bone marrow-derived monocytes into dendritic cells [121].

In pathological conditions, the RAS-dependent differentiation of monocytes into macrophages is disturbed and the two RAS axes oppose their actions. TNF- $\alpha$ downregulates the ACE in human peripheral blood monocytes, thus impairing Ang-II production [122]. AT1R induces oxidative stress in macrophages derived from the human monocytic leukemia cell line THP-1 [114], and in turn, AT1R expression increases in peritoneal macrophages exposed to oxidative stress [113]. In patients on maintenance hemodialysis, losartan (ARB) prevents the development of circulating proinflammatory monocytes [123], suggesting that ARB could regulate the inflammatory status of monocytes in vivo before their recruitment into the inflamed tissues. In patients with atherosclerosis, AT1R favors macrophage infiltration in atherosclerotic lesions as shown by the inhibition of macrophage infiltration in carotid plaques from patients treated with candesartan (ARB) as compared to patients without candesartan [124]. In the murine macrophage Raw 264.7 cell line, Ang-II, irrespective of its receptor, induces the M1 phenotype as measured by the production of the high-mobility group box-1, a DNA damage reparatory protein associated with inflammation [125]. In the same cells, Ang-II promotes macrophage polarization toward the M1 phenotype, also through the connexin 43/NF kappa B signaling [126]. In human primary macrophages, LPS treatment increases the AT1R expression and ARB blocks the secretion 
of proinflammatory cytokines [124]. In atherosclerosis, the MR seems to promote the M1 macrophage phenotype [117].

MASR is expressed on different subsets of mouse primary macrophages without any difference in expression between unstimulated, LPS/IFN $\gamma$-, IL-4/IL-13- and IL-4-polarized macrophages $[127,128]$. MASR deficiency stimulates the expressions of M1 markers in LPS/IFN $\gamma$ and inhibits the expression of M2 markers in IL-4/IL-13-treated macrophages. MASR stimulation by Ang-(1,7) decreases the expression of M1 markers in LPS- [129] or LPS/IFN $\gamma$-stimulated mouse peritoneal macrophages [128]. Moreover, Ang-(1,7) treatment increases mRNA expression of YM1, an M2 marker, in mouse macrophages stimulated by IL-4 [128]. The anti-inflammatory action of Ang-(1,7) depends on MASR stimulation through inhibition of the TLR4-mediated JNK/FoxO1 signaling pathway in LPS-treated RAW macrophages [130]. MASR knockout increases in vitro migration and T cell activation capacities of peritoneal mouse macrophages [127]. ACE2 overexpression is associated with a significant reduction of Ang-II-induced MCP-1 in THP-1 macrophages [131].

Interestingly, human peripheral blood mononuclear cells exposed to pharmacological doses of renin produce proinflammatory cytokines IL-6, TNF- $\alpha$ and IFN $\gamma$ independently from the Ang-II-AT1R pathway [119]. Actually, besides its enzymatic role, PRR triggers macrophage infiltration in glomerulonephritis [132] and chronic kidney disease-associated heart failure [133]. More investigations are needed to explore the role of PRR in monocyte/macrophage recruitment and polarization in DN.

Taken as a whole, the ACE, Ang-II, AT1R, MR axis intrinsic to monocytes/macrophages is stimulated in inflammatory conditions and promotes the pro-inflammatory M1 phenotype, whereas the Ang-(1,7), ACE2, MASR axis potentiates the polarization of macrophages into an anti-inflammatory M2 subset.

\subsection{Modulation of Monocyte Recruitment by the RAS in DN}

The ACE, Ang-II, AT1R, MR axis enhances the adhesion of human peripheral monocytes to monolayers of human endothelial cells [134]. P-selectin, E-selectin, ICAM-1 and VCAM-1 expression increases in arterioles and venules of Ang-II-treated rats [135] as well as in aortas of Ang-II-infused rats [136]. Intraperitoneal injection of Ang-II in rats promotes the adhesion of mononuclear cells to arterioles depending on P-selectin and integrin beta 2 [135]. In vitro and in vivo experiments show that Ang-II promotes monocyte adhesion to endothelial cells and migration through ICAM-1 [137]. Since some of these adhesion molecules are upregulated in DN [58,64-66], renal production of Ang-II could stimulate their expression in renal endothelial cells to promote migration of monocytes into the kidneys.

Highlighting the role of the RAS intrinsic to the kidneys for monocyte recruitment in DN (Table 2), activation of the ACE and AT1R promotes the accumulation of macrophages in the kidneys of STZ-treated mice through increased MCP-1 expression and NF kappa B activity $[138,139]$. Renal subcapsular administration of valsartan (ARB) reduces the renal macrophage infiltration in STZ-treated mice [138]. In animal models of DN with hypertension, ACEI decrease the kidney macrophage count. Indeed, in STZ-treated Ren2 rats, perindopril (ACEI) reduces renal fibrosis [33] and macrophage infiltration [140] depending on OPN [80]. The role of OPN is further documented in OLETF rats treated with ramipril (ACEI) [75]. Similar to the reno-protective effect of ramipril in human patients with DN [106], captopril (ACEI) inhibits renal macrophage infiltration in the kidneys from STZ-treated hypertensive Nos3 $3^{-1-}$ mice even when blood pressure values are controlled with a diuretic [52]. Further, captopril administration reduces both renal macrophage infiltration and renal fibrosis in $\mathrm{db} / \mathrm{db}$ mice [141]. Similarly, olmesartan (ARB) decreases interstitial fibrosis and renal macrophage count in STZ-treated rats [142]. Reduction of interstitial fibrosis and decreased expression of the TGF- $\beta$ protein and of the NF kappa B activity in the kidneys from STZ-treated rats are obtained with telmisartan (ARB) associated with thiorphan (NEPI) or an ACE2 activator (Dize) [100]. More directly, cyclic (c)Ang- 
$(1,7)$ administration in ob/ob mice decreases the amount of interstitial and glomerular macrophages in the kidneys [143].

Table 2. Effects of modulation of the RAS on monocyte/macrophage recruitment and polarization in animal models of DN.

\begin{tabular}{|c|c|c|c|c|}
\hline Diabetic Models & Strategies & $\begin{array}{l}\text { Effects on Macrophage } \\
\text { Recruitment and Polarization } \\
\text { in Kidneys }\end{array}$ & Renal Effects & Ref. \\
\hline \multirow[t]{2}{*}{ STZ-treated mice } & enalapril (ACEI) & $\begin{array}{c}\uparrow \text { blood leucocytes and } \\
\text { CD68 }{ }^{+} \mathrm{F} 4 / 80^{+} \text {cell number, } \uparrow \\
\mathrm{CD} 206 \text { (M2 marker) expression } \\
\text { in renal macrophages, } \uparrow \\
\text { fractalkine renal expression }\end{array}$ & $\begin{array}{l}\downarrow 24 \text { - } h \text { albuminuria in } \\
\text { metabolic cages }\end{array}$ & [144] \\
\hline & $\begin{array}{c}\text { subcapsular implantation } \\
\text { of a valsartan (ARB) } \\
\text { delivery sponge in } \\
\text { the kidneys }\end{array}$ & $\downarrow$ macrophage infiltration & no effect & [138] \\
\hline $\begin{array}{l}\text { STZ-treated } \\
\text { hypertensive } \\
\text { Nos3 }^{-/-} \text {mice }\end{array}$ & $\begin{array}{l}\text { CCR2 antagonist and/or } \\
\text { captopril (ACEI) }\end{array}$ & $\begin{array}{l}\downarrow \text { macrophage infiltration with a } \\
\text { CCR2 antagonist, additional } \\
\text { effect with captopril }\end{array}$ & $\begin{array}{c}\downarrow \text { UACR with CCR2 } \\
\text { antagonist and collagen IV } \\
\text { deposition in glomeruli, no } \\
\text { additional effect } \\
\text { with captopril }\end{array}$ & [52] \\
\hline \multirow{4}{*}{ STZ-treated rats } & olmesartan (ARB) & $\downarrow$ macrophage infiltration & $\begin{array}{l}\downarrow \text { glomerulosclerosis, } \\
\text { interstitial fibrosis }\end{array}$ & [142] \\
\hline & $\begin{array}{l}\text { losartan (ARB) and/or } \\
\text { mycophenolate mofetil } \\
\text { (macrophage infiltration } \\
\text { and proliferation } \\
\text { suppressor) }\end{array}$ & $\begin{array}{l}\downarrow \text { macrophage infiltration and } \\
\text { MCP-1 renal expression, } \\
\text { additional effect with } \\
\text { mycophenolate mofetil, no effect } \\
\text { on ICAM-1 expression }\end{array}$ & $\begin{array}{l}\downarrow \text { kidney weight and } \\
\text { glomerulosclerosis, } \\
\text { additional effect with } \\
\text { mycophenolate mofetil }\end{array}$ & [145] \\
\hline & $\begin{array}{l}\text { candesartan (ARB) or } \\
\text { enalapril (ACEI) }\end{array}$ & $\begin{array}{l}\downarrow \mathrm{MCP}-1 \text { renal expression and } \\
\text { macrophage infiltration }\end{array}$ & $\downarrow$ kidney weight & [139] \\
\hline & $\begin{array}{l}\text { thiorphan (NEPI) or } \\
\text { diminazene aceturate } \\
\text { (ACE2 activator) and } \\
\text { telmisartan (ARB) }\end{array}$ & not available & $\begin{array}{c}\downarrow \text { glomerular and } \\
\text { tubulointerstitial fibrosis }\end{array}$ & [100] \\
\hline \multirow{2}{*}{$\begin{array}{l}\text { STZ-treated } \\
\text { hypertensive } \\
\text { REN-2 rats }\end{array}$} & no treatment & not available & $\begin{array}{c}\text { severe glomerulosclerosis, } \\
\text { low GFR }\end{array}$ & [33] \\
\hline & perindopril (ACEI) & $\downarrow$ macrophage infiltration & $\begin{array}{l}\downarrow \text { renal fibrosis and } \\
\text { protection against } \\
\text { GFR decrease }\end{array}$ & [140] \\
\hline $\mathrm{db} / \mathrm{db}$ mice & enalapril (ACEI) & $\begin{array}{c}\uparrow \text { blood leucocyte and } \\
\text { macrophage number, } \uparrow \text { CD11c } \\
\text { (M1 marker) expression in } \\
\text { renal macrophages }\end{array}$ & $\begin{array}{l}\downarrow 24 \text {-h albuminuria in } \\
\text { metabolic cages }\end{array}$ & [144] \\
\hline $\mathrm{ob} / \mathrm{ob}$ mice & $\begin{array}{l}\text { cAng-(1,7) and/or } \\
\text { lisinopril (ACEI) }\end{array}$ & $\begin{array}{l}\downarrow \text { macrophage infiltration, } \\
\text { additional effect with lisinopril }\end{array}$ & $\begin{array}{c}\downarrow \text { glomerulosclerosis, } \\
\text { albuminuria, renal fibrosis, } \\
\text { additional effect } \\
\text { with lisinopril }\end{array}$ & [143] \\
\hline $\begin{array}{l}e \mathrm{Nos}^{-/-} \text {and } \\
\mathrm{db} / \mathrm{db} \text { mice }\end{array}$ & captopril (ACEI) & $\begin{array}{l}\downarrow \text { macrophage infiltration, } \uparrow \\
\text { arginase- } 1 \text { and IL4-RA (M2 } \\
\text { markers) expression }\end{array}$ & $\begin{array}{c}\downarrow \text { UACR, } \\
\text { glomerulosclerosis and } \\
\text { interstitial fibrosis }\end{array}$ & [141] \\
\hline $\begin{array}{l}\text { Otsuka Long-Evans } \\
\text { Tokushima fatty rats }\end{array}$ & ramipril (ACEI) & $\begin{array}{c}\downarrow \text { macrophage infiltration and } \\
\text { osteopontin expression }\end{array}$ & $\begin{array}{l}\downarrow \text { glomerulosclerosis and } \\
\text { tubulointerstitial fibrosis }\end{array}$ & [75] \\
\hline
\end{tabular}

Abbreviations: ACE2, angiotensin-converting enzyme type 2; ACEI, angiotensin-converting enzyme inhibitors; ARB, angiotensin II receptor blockers; cAng-(1,7), cyclic angiotensin 1,7; CCR2, C-C chemokine receptor type 2; eNOS, endothelial nitric oxide synthase; GFR, glomerular filtration rate; ICAM-1, intracellular adhesion molecule-1; IL4-RA, interleukin 4 receptor alpha; MCP-1, monocyte chemoattractant protein-1; NEPI, neprilysin inhibitors; Nos3, nitric oxide synthase 3; STZ, streptozotocin; UACR, urinary albumin-to-creatinine ratio.

Despite the presence of the MR on macrophages [117], its role regarding renal macrophage infiltration or polarization in animal models of DN is not yet documented. However, a 12-week treatment of enalapril (ACEI) in STZ-treated mice or $\mathrm{db} / \mathrm{db}$ mice does not reduce the expression of the CD11c marker of M1 macrophages in the kidneys. Indeed, CD11c 
positivity is even higher in enalapril-treated mice than in their untreated counterparts [144]. With regard to intrarenal overproduction of aldosterone in the urine, which is not lowered by enalapril in $\mathrm{db} / \mathrm{db}$ mice [146], this paradoxical phenomenon may be due to the stimulation of the MR on macrophages. In line with this interpretation, albuminuria is suppressed at week 6 and not any longer at week 12 [144], suggesting that aldosterone might increase albuminuria [147] despite ACE inhibition.

Together, these studies demonstrate that beneficial effects of ACEI or ARB (and maybe of MRA) on renal function, albuminuria and fibrosis are associated with a decreased macrophage count intrinsic to the kidneys (Figure 2). The role of stimulation of the Ang$(1,7)$, ACE2, MASR axis regarding renal macrophage infiltration remains to be elucidated in $\mathrm{DN}$.

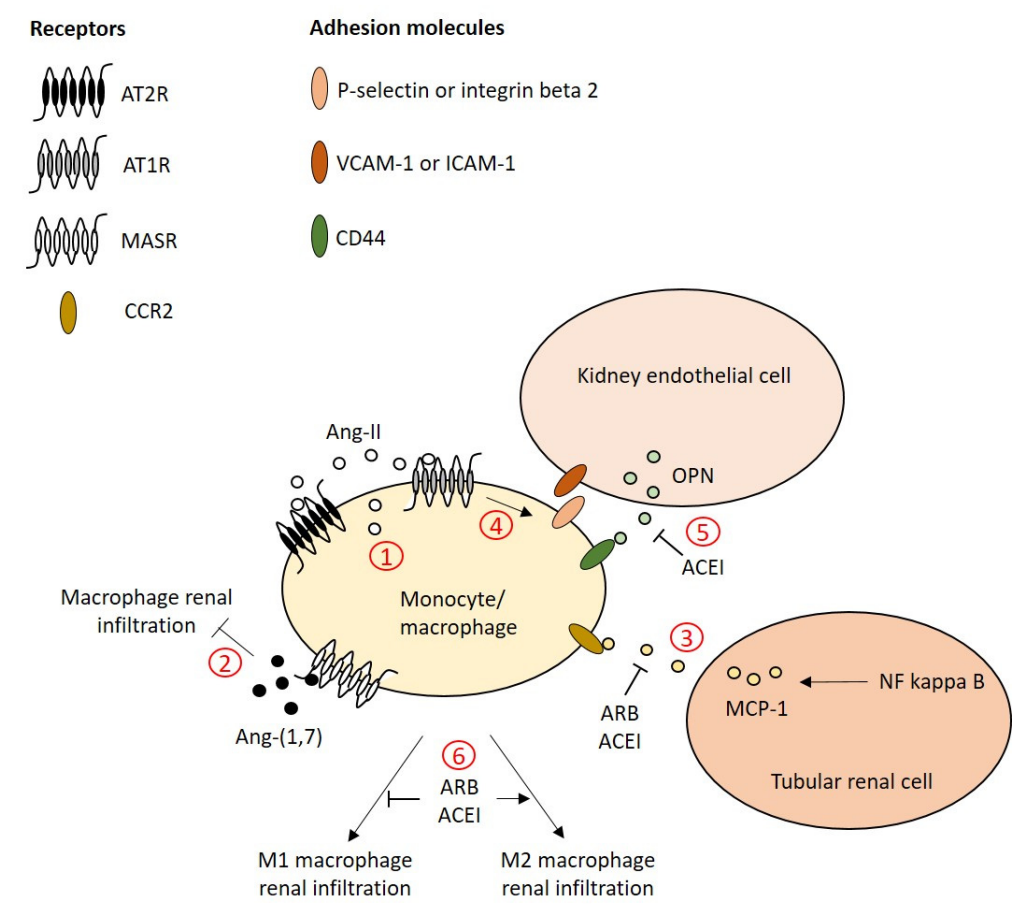

Figure 2. Working model of the RAS-dependent control of monocytes/macrophages in DN. 1. Ang-II is overproduced in the kidneys from diabetic animals and can be released by resident monocytes/macrophages. The RAS system regulates monocyte chemotaxis and recruitment and macrophage polarization in DN. 2. Ang- $(1,7)$ administration inhibits macrophage infiltration in the kidneys. 3. NF kappa B-dependent MCP-1 secretion by tubular renal cells is induced by the Ang-II, AT1R axis. 4. In monocytes, Ang-II stimulates the expression of P-selectin and integrin beta 2 that bind to adhesion molecules, ICAM-1 and VCAM-1, on the surface of endothelial cells. 5. The adhesion of monocytes also involves OPN that is secreted by endothelial cells and then OPN binds to its receptor CD44 on the surface of monocytes. The release of renal OPN depends on the activation of the Ang-II, ACE, AT1R axis. 6. Finally, inhibition of the Ang-II, ACE, AT1R axis in macrophages and/or in the kidney microenvironment induces a switch from the M1 to the M2 macrophage subset alleviating proinflammatory signals and promoting wound healing. Abbreviations: ACEI, angiotensin-converting enzyme inhibitor; Ang, angiotensin; ARB, angiotensin receptor blockers; AT1R, Ang-II receptor type 1; AT2R, Ang-II receptor type 1; CCR2, C-C chemokine receptor type 2; ICAM-1, intracellular adhesion molecule-1; MASR, Mas receptor; MCP-1, monocyte chemoattractant protein-1; NF kappa B, nuclear factor kappa-B; OPN, osteopontin; VCAM-1, vascular cell adhesion molecule-1.

\subsection{Modulation of Macrophage Polarization by the RAS in DN}

The RAS-dependent regulation of macrophage polarization in diabetic kidneys is scarcely documented, but this research field could be more widely studied thanks to technical advances. Indeed, reliable and highly efficient isolation of immune cells from the 
kidneys has emerged thanks to the development of mechanical tissue disruptors without the collagenase digestion step [148].

Vitamin D treatment, which inhibits the Ang-II, ACE, AT1R, MR axis of the RAS, decreases the number of M1 macrophages, increases the number of M2 macrophages and reduces albuminuria in STZ-treated rats [54]. Losartan induces a phenotype switch in the infiltrated renal macrophages in obese mice following a high-fat diet by increasing M2 markers and decreasing M1 markers [149]. In apolipoprotein E-deficient mice with renal failure induced by the removal of one entire kidney, the administration of bone marrow cells from At1r ${ }^{-/}$mice increases the M2 macrophage count in the remaining kidney [150]. Captopril administration in hypertensive eNos ${ }^{-1-} \mathrm{db} / \mathrm{db}$ mice enhances the expression of M2 markers in the kidneys [141]. Together, these studies suggest that suppression of the Ang-II, ACE, AT1R, MR axis may switch the renal macrophage phenotype from M1 to M2 and contribute to protecting the kidneys from diabetes-related injuries (Figure 2).

Some data suggest that telmisartan (ARB) could modulate the macrophage phenotype. Indeed, telmisartan represses MCP-1 expression from peripheral monocytes in patients with essential hypertension [151] and drives monocytes to M2 macrophage polarization in mice following stimulation of peroxisome proliferator-activated receptor gamma (PPAR$\gamma$ ) [152]. Therefore, telmisartan could promote the differentiation of peripheral monocytes toward the M2 macrophage phenotype in patients with $\mathrm{DN}$. To test this hypothesis, a pilot prospective and randomized study was performed at our hospital (NCT02768948). One hundred fifty-four patients with T2D were screened and 24 patients were included with a DN characterized by a GFR $>30 \mathrm{~mL} / \mathrm{min} / 1.73 \mathrm{~m}^{2}$, micro- or macroalbuminuria without nephrotic proteinuria and hypertension treated with ACEI or ARB. The patients were assigned $80 \mathrm{mg}$ telmisartan or $100 \mathrm{mg}$ losartan daily, as already done in the AMADEO study [153], and they were randomized in order to prevent the confounding effects of various levels of albuminuria on the renal production of MCP-1 since telmisartan is more efficient than losartan in reducing albuminuria [153]. The primary goal was to compare the in vitro polarization potential of circulating monocytes from patients treated with losartan or telmisartan. After six months of treatment, peripheral blood mononuclear cells from these patients were collected to isolate monocytes that were in vitro differentiated into resting macrophages (RM, used as control), M1 macrophages (in the presence of IL-1 $\beta$ ) or M2 macrophages (in the presence of IL-4). The secondary objective was to compare the variation of urinary MCP- 1 over the creatinine ratio between the losartan and telmisartan groups. Four patients were lost to follow-up, three more patients were not compliant with the study and one was excluded following a rapid decline of the GFR. The data from 16 patients were analyzed: eight patients were treated with losartan and eight patients were treated with telmisartan. The mean age was $68 \pm 7$ years, the mean GFR was $54 \pm 17 \mathrm{~mL} / \mathrm{min} / 1.73 \mathrm{~m}^{2}$, the body mass index was $29 \pm 5 \mathrm{~kg} / \mathrm{m}^{2}$, the UACR was $342 \pm 540 \mathrm{mg} / \mathrm{g}$ and $\mathrm{HbA1c}$ was $7.3 \pm 1.4 \%$. There was no difference in urinary excretion of MCP-1 between the two groups. The fold changes of mRNA expression of M2 or M1 markers (compared to the respective RM) were similar in the two groups (Figure 3A). For each patient, the M2/M1 score was also calculated, corresponding to the ratio of the number of M2 markers to the number of M1 markers that were overexpressed in response to IL-4 or IL-1 $\beta$, respectively. A score greater than 1 means that macrophages from the patient respond better to stimulation with IL-4 than with IL-1 $\beta$. Macrophages from 13 patients (six patients with losartan and seven patients with telmisartan) had a score over 1 without differences with respect to losartan and telmisartan administration (Figure 3B). In other words, polarization of macrophages from patients treated with losartan or telmisartan was altered. This specificity of macrophage polarization could depend on DN as well as on the effect of ARB. These results also suggest that ARB therapy could condition macrophages to be less receptive to a deleterious proinflammatory renal environment while retaining their potential to differentiate into the renoprotective M2 phenotype. 
A.

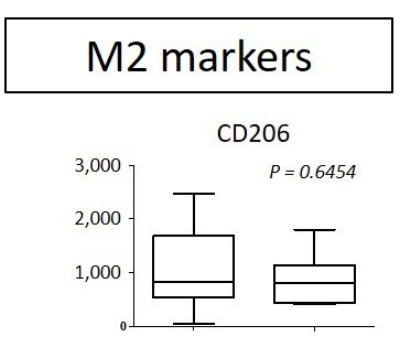

CD200R
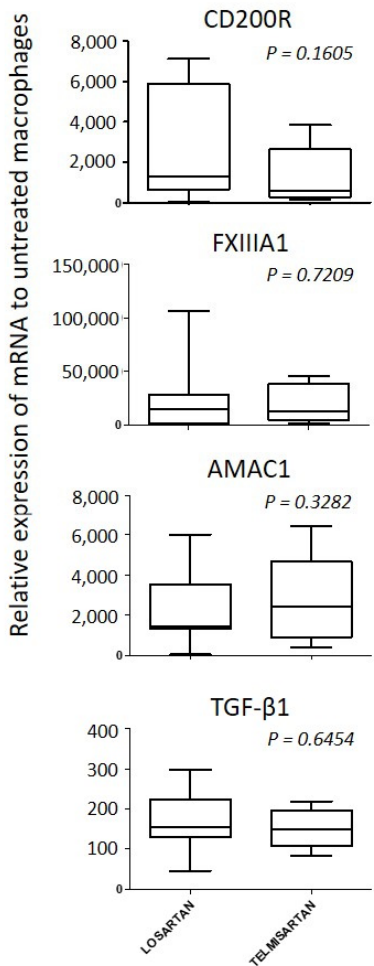

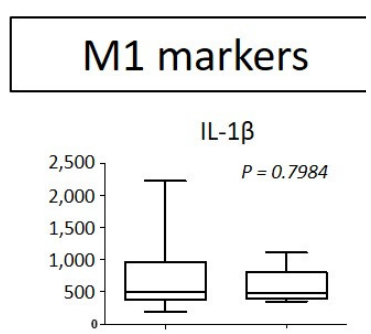

IL-6

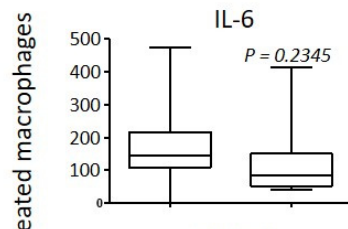

TNF- $\alpha$

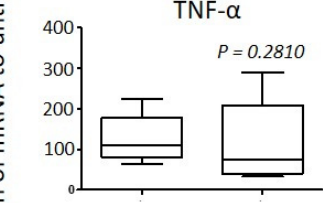

CCL2

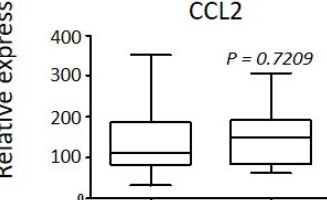

CCL3

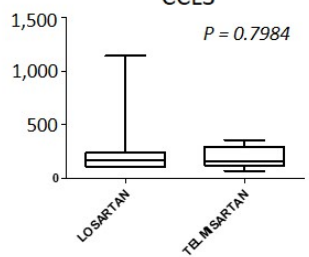

B.

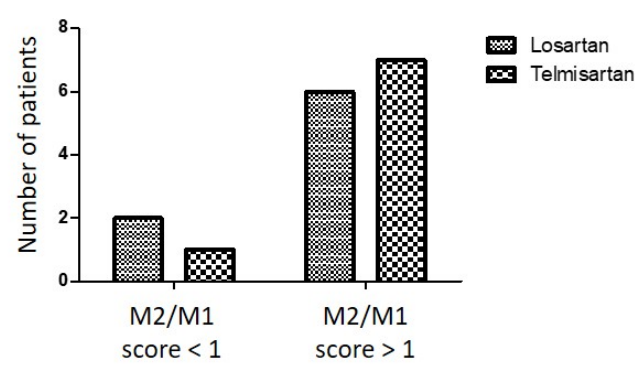

Figure 3. Relative expression of M1 and M2 markers in monocyte-derived macrophages from patients with DN treated with losartan or telmisartan. Blood monocytes isolated from 16 patients treated with losartan or telmisartan (eight per group) for six months were differentiated in vitro into macrophages without cytokines (RM, resting macrophages) or in the presence of $15 \mathrm{ng} / \mathrm{mL}$ of IL-1 $\beta$ (M1 macrophages) or IL-4 (M2 macrophages). After six days of differentiation, total RNA was extracted and mRNA expression of M1 (IL-1B, IL-6, CCL2, TNF- $\alpha$ and CCL3) and M2 markers (CD206, CD200R, FXIIIA1, TGF- $\beta 1$ and AMAC-1) measured by Q-PCR and expressed relative to RM (M2 markers, left panel; M1 markers, right panel). (A) The data are presented as the medians (interquartile ranges) and compared using the Mann-Whitney test. The $p$-value between the losartan group versus the telmisartan group is shown. (B) Numbers of patients with the M2/M1 score $<1$ or $>1$ in the telmisartan group and the losartan group. Abbreviations: AMAC1, alternative macrophage activation-associated CC-chemokine 1; CCL2 or CCL3, C-C motif chemokine ligand 2 or 3; FXIIIA1, coagulation factor XIII A1; IL, interleukin; TGF- $\beta 1$, transforming growth factor beta 1 ; TNF- $\alpha$, tumor necrosis factor alpha. 


\section{Conclusions}

The RAS intrinsic to the kidneys and monocyte/macrophage interactions may worsen the lesions of DN. Consequently, they both offer therapeutic targets to preserve the renal function in patients with DN. Osteopontin, $\mathrm{MCP}-1$ and their respective receptors on monocytes, CD44 and CCR2, are intermediate links between the RAS pathways and monocytes/macrophages. Targeting these molecules in experimental DN limits the recruitment of monocytes into the kidneys and protects the kidneys from diabetes-induced injuries. Some clinical trials targeting leukocyte recruitment with MCP-1 or CCR2 inhibitors or antiinflammatory molecules are in progress in patients with DN treated with RAS blockers [154].

Suppressing the ACE, Ang-II, AT1R, MR axis of the RAS is the classical treatment of DN, which acts partly by blocking the recruitment of monocytes into the kidneys and by increasing the M2/M1 polarization ratio in kidney-resident macrophages. As M2 macrophages have a kidney-protective role in $\mathrm{DN}$, more experimental work is needed to understand the underlying mechanisms of the modulation of the macrophage phenotype by the RAS in DN. In particular, the effects of the activation of the Ang-(1,7), ACE2, AT2R, MASR axis and the effect of PRR or MR blockade on macrophage polarization have to be investigated in the context of DN. Data from such studies could open new therapeutic avenues to prevent the evolution of DN towards end-stage renal disease.

Author Contributions: C.M.-writing the manuscript, acquisition of data, data analysis/interpretation, critical revision of the manuscript and approval of the final version; A.L.-patient inclusion, acquisition of data and approval of the final version; M.N.-acquisition of data and approval of the final version; T.F.-patient inclusion, acquisition of data, data analysis/interpretation and approval of the final version, V.E.--formation of concept/design and approval of the final version; J.G.N.—critical revision of the manuscript and approval of the final version; N.C.-patient inclusion, critical revision of the manuscript and approval of the final version; G.C.--formation of concept/design, data analysis/interpretation, critical revision of the manuscript and approval of the final version; G.F.-writing the manuscript, formation of concept/design, data analysis/interpretation, critical revision of the manuscript and approval of the final version. All authors have read and agreed to the published version of the manuscript.

Funding: This work was sponsored by Centre Hospitalier Universitaire de Nice (University Hospital of Nice) for regulatory and ethics approval. This work was supported by a grant from the Department of Clinical Research and Innovation of the University Hospital of Nice 2016 (NCT02768948). This research was funded by Agence Nationale de la Recherche (AlMaVasCal project (ANR-16-CE14-000101)) (G.C).

Institutional Review Board Statement: The study was conducted according to the guidelines of the Declaration of Helsinki, and approved by the following Ethics Committee: "Comite de Protection des Personnes Sud-Méditerranée", protocol code 2016-002009-20, approved on the 22nd, May 2017).

Informed Consent Statement: Informed consent was obtained from all subjects involved in the study.

Acknowledgments: We greatly acknowledge Céline Fernandez (clinic research associate, CHU, Nice, France) for her involvement in the inclusion of patients.

Conflicts of Interest: The authors declare no conflict of interest.

\section{References}

1. Barutta, F.; Bruno, G.; Grimaldi, S.; Gruden, G. Inflammation in Diabetic Nephropathy: Moving toward Clinical Biomarkers and Targets for Treatment. Endocrine 2015, 48, 730-742. [CrossRef]

2. Calle, P.; Hotter, G. Macrophage Phenotype and Fibrosis in Diabetic Nephropathy. Int. J. Mol. Sci. 2020, 21, 2806. [CrossRef]

3. McKinney, C.A.; Fattah, C.; Loughrey, C.M.; Milligan, G.; Nicklin, S.A. Angiotensin-(1-7) and Angiotensin-(1-9): Function in Cardiac and Vascular Remodelling. Clin. Sci. (Lond) 2014, 126, 815-827. [CrossRef]

4. Yang, T.; Xu, C. Physiology and Pathophysiology of the Intrarenal Renin-Angiotensin System: An Update. J. Am. Soc. Nephrol. 2017, 28, 1040-1049. [CrossRef]

5. Carey, R.M.; Siragy, H.M. The Intrarenal Renin-Angiotensin System and Diabetic Nephropathy. Trends Endocrinol. Metab. 2003, 14, 274-281. [CrossRef] 
6. Sparks, M.A.; Crowley, S.D.; Gurley, S.B.; Mirotsou, M.; Coffman, T.M. Classical Renin-Angiotensin System in Kidney Physiology. Compr. Physiol. 2014, 4, 1201-1228. [CrossRef]

7. Hammer, A.; Stegbauer, J.; Linker, R.A. Macrophages in Neuroinflammation: Role of the Renin-Angiotensin-System. Pflugers Arch. 2017, 469, 431-444. [CrossRef] [PubMed]

8. Nehme, A.; Zibara, K. Cellular Distribution and Interaction between Extended Renin-Angiotensin-Aldosterone System Pathways in Atheroma. Atherosclerosis 2017, 263, 334-342. [CrossRef] [PubMed]

9. Ruiz-Ortega, M.; Rupérez, M.; Esteban, V.; Rodríguez-Vita, J.; Sánchez-López, E.; Carvajal, G.; Egido, J. Angiotensin II: A Key Factor in the Inflammatory and Fibrotic Response in Kidney Diseases. Nephrol. Dial. Transplant. 2006, 21, 16-20. [CrossRef] [PubMed]

10. Siragy, H.M.; Carey, R.M. Role of the Intrarenal Renin-Angiotensin-Aldosterone System in Chronic Kidney Disease. Am. J. Nephrol. 2010, 31, 541-550. [CrossRef]

11. Roscioni, S.S.; Heerspink, H.J.L.; de Zeeuw, D. The Effect of RAAS Blockade on the Progression of Diabetic Nephropathy. Nat. Rev. Nephrol. 2014, 10, 77-87. [CrossRef] [PubMed]

12. Vallon, V.; Komers, R. Pathophysiology of the Diabetic Kidney. Compr. Physiol. 2011, 1, 1175-1232. [CrossRef]

13. Ruggenenti, P.; Porrini, E.L.; Gaspari, F.; Motterlini, N.; Cannata, A.; Carrara, F.; Cella, C.; Ferrari, S.; Stucchi, N.; Parvanova, A.; et al. Glomerular Hyperfiltration and Renal Disease Progression in Type 2 Diabetes. Diabetes Care 2012, 35, 2061-2068. [CrossRef] [PubMed]

14. Brenner, B.M. Hemodynamically Mediated Glomerular Injury and the Progressive Nature of Kidney Disease. Kidney Int. 1983, 23, 647-655. [CrossRef]

15. Halimi, J.M. The Emerging Concept of Chronic Kidney Disease without Clinical Proteinuria in Diabetic Patients. Diabetes Metab 2012, 38, 291-297. [CrossRef]

16. Tervaert, T.W.C.; Mooyaart, A.L.; Amann, K.; Cohen, A.H.; Cook, H.T.; Drachenberg, C.B.; Ferrario, F.; Fogo, A.B.; Haas, M.; de Heer, E.; et al. Pathologic Classification of Diabetic Nephropathy. J. Am. Soc. Nephrol. 2010, 21, 556-563. [CrossRef]

17. Schainuck, L.I.; Striker, G.E.; Cutler, R.E.; Benditt, E.P. Structural-Functional Correlations in Renal Disease. II. The Correlations. Hum. Pathol. 1970, 1, 631-641. [CrossRef]

18. Striker, G.E.; Schainuck, L.I.; Cutler, R.E.; Benditt, E.P. Structural-Functional Correlations in Renal Disease. I. A Method for Assaying and Classifying Histopathologic Changes in Renal Disease. Hum. Pathol. 1970, 1, 615-630. [CrossRef]

19. Bohle, A.; Wehrmann, M.; Bogenschütz, O.; Batz, C.; Müller, C.A.; Müller, G.A. The Pathogenesis of Chronic Renal Failure in Diabetic Nephropathy. Investigation of 488 Cases of Diabetic Glomerulosclerosis. Pathol. Res. Pract. 1991, 187, 251-259. [CrossRef]

20. Liu, Y. Cellular and Molecular Mechanisms of Renal Fibrosis. Nat. Rev. Nephrol. 2011, 7, 684-696. [CrossRef]

21. Brownlee, M. The Pathobiology of Diabetic Complications: A Unifying Mechanism. Diabetes 2005, 54, 1615-1625. [CrossRef]

22. Tesch, G.H. Diabetic Nephropathy-Is This an Immune Disorder? Clin. Sci. (Lond) 2017, 131, 2183-2199. [CrossRef]

23. Navarro-González, J.F.; Mora-Fernández, C.; Muros de Fuentes, M.; García-Pérez, J. Inflammatory Molecules and Pathways in the Pathogenesis of Diabetic Nephropathy. Nat. Rev. Nephrol. 2011, 7, 327-340. [CrossRef] [PubMed]

24. Furuta, T.; Saito, T.; Ootaka, T.; Soma, J.; Obara, K.; Abe, K.; Yoshinaga, K. The Role of Macrophages in Diabetic Glomerulosclerosis. Am. J. Kidney Dis. 1993, 21, 480-485. [CrossRef]

25. Zhang, X.; Yang, Y.; Zhao, Y. Macrophage Phenotype and Its Relationship with Renal Function in Human Diabetic Nephropathy. PLoS ONE 2019, 14, e0221991. [CrossRef] [PubMed]

26. Klessens, C.Q.F.; Zandbergen, M.; Wolterbeek, R.; Bruijn, J.A.; Rabelink, T.J.; Bajema, I.M.; IJpelaar, D.H.T. Macrophages in Diabetic Nephropathy in Patients with Type 2 Diabetes. Nephrol. Dial. Transplant. 2017, 32, 1322-1329. [CrossRef] [PubMed]

27. Alpers, C.E.; Hudkins, K.L. Mouse Models of Diabetic Nephropathy. Curr. Opin Nephrol. Hypertens 2011, 20, 278-284. [CrossRef]

28. Kawano, K.; Hirashima, T.; Mori, S.; Saitoh, Y.; Kurosumi, M.; Natori, T. Spontaneous Long-Term Hyperglycemic Rat with Diabetic Complications. Otsuka Long-Evans Tokushima Fatty (OLETF) Strain. Diabetes 1992, 41, 1422-1428. [CrossRef] [PubMed]

29. Nath, S.; Ghosh, S.K.; Choudhury, Y. A Murine Model of Type 2 Diabetes Mellitus Developed Using a Combination of High Fat Diet and Multiple Low Doses of Streptozotocin Treatment Mimics the Metabolic Characteristics of Type 2 Diabetes Mellitus in Humans. J. Pharmacol. Toxicol. Methods 2017, 84, 20-30. [CrossRef] [PubMed]

30. Baig, M.A.; Panchal, S.S. Streptozotocin-Induced Diabetes Mellitus in Neonatal Rats: An Insight into Its Applications to Induce Diabetic Complications. Curr. Diabetes Rev. 2019, 16, 26-39. [CrossRef]

31. Pérez-López, L.; Boronat, M.; Melián, C.; Brito-Casillas, Y.; Wägner, A.M. Animal Models and Renal Biomarkers of Diabetic Nephropathy. Adv. Exp. Med. Biol. 2021, 1307, 521-551. [CrossRef]

32. Nakagawa, T.; Sato, W.; Glushakova, O.; Heinig, M.; Clarke, T.; Campbell-Thompson, M.; Yuzawa, Y.; Atkinson, M.A.; Johnson, R.J.; Croker, B. Diabetic Endothelial Nitric Oxide Synthase Knockout Mice Develop Advanced Diabetic Nephropathy. J. Am. Soc. Nephrol. 2007, 18, 539-550. [CrossRef]

33. Kelly, D.J.; Wilkinson-Berka, J.L.; Allen, T.J.; Cooper, M.E.; Skinner, S.L. A New Model of Diabetic Nephropathy with Progressive Renal Impairment in the Transgenic (MRen-2)27 Rat (TGR). Kidney Int. 1998, 54, 343-352. [CrossRef]

34. Munro, D.A.D.; Hughes, J. The Origins and Functions of Tissue-Resident Macrophages in Kidney Development. Front. Physiol. 2017, 8, 837. [CrossRef] [PubMed]

35. Wang, Y.; Harris, D.C.H. Macrophages in Renal Disease. J. Am. Soc. Nephrol. 2011, 22, 21-27. [CrossRef] 
36. You, H.; Gao, T.; Cooper, T.K.; Brian Reeves, W.; Awad, A.S. Macrophages Directly Mediate Diabetic Renal Injury. Am. J. Physiol. Renal. Physiol. 2013, 305, F1719-F1727. [CrossRef] [PubMed]

37. Li, J.J.; Lee, S.H.; Kim, D.K.; Jin, R.; Jung, D.-S.; Kwak, S.-J.; Kim, S.H.; Han, S.H.; Lee, J.E.; Moon, S.J.; et al. Colchicine Attenuates Inflammatory Cell Infiltration and Extracellular Matrix Accumulation in Diabetic Nephropathy. Am. J. Physiol. Renal. Physiol. 2009, 297, F200-F209. [CrossRef]

38. Yuan, Y.; Li, L.; Zhu, L.; Liu, F.; Tang, X.; Liao, G.; Liu, J.; Cheng, J.; Chen, Y.; Lu, Y. Mesenchymal Stem Cells Elicit Macrophages into M2 Phenotype via Improving Transcription Factor EB-Mediated Autophagy to Alleviate Diabetic Nephropathy. Stem. Cells 2020, 38, 639-652. [CrossRef] [PubMed]

39. Cailhier, J.F.; Partolina, M.; Vuthoori, S.; Wu, S.; Ko, K.; Watson, S.; Savill, J.; Hughes, J.; Lang, R.A. Conditional Macrophage Ablation Demonstrates That Resident Macrophages Initiate Acute Peritoneal Inflammation. J. Immunol. 2005, 174, $2336-2342$. [CrossRef]

40. Chow, F.Y.; Nikolic-Paterson, D.J.; Ozols, E.; Atkins, R.C.; Rollin, B.J.; Tesch, G.H. Monocyte Chemoattractant Protein-1 Promotes the Development of Diabetic Renal Injury in Streptozotocin-Treated Mice. Kidney Int. 2006, 69, 73-80. [CrossRef]

41. Kanamori, H.; Matsubara, T.; Mima, A.; Sumi, E.; Nagai, K.; Takahashi, T.; Abe, H.; Iehara, N.; Fukatsu, A.; Okamoto, H.; et al. Inhibition of MCP-1/CCR2 Pathway Ameliorates the Development of Diabetic Nephropathy. Biochem. Biophys. Res. Commun. 2007, 360, 772-777. [CrossRef]

42. Song, K.H.; Park, J.; Park, J.H.; Natarajan, R.; Ha, H. Fractalkine and Its Receptor Mediate Extracellular Matrix Accumulation in Diabetic Nephropathy in Mice. Diabetologia 2013, 56, 1661-1669. [CrossRef]

43. Cui, S.; Zhu, Y.; Du, J.; Khan, M.N.; Wang, B.; Wei, J.; Cheng, J.-W.; Gordon, J.R.; Mu, Y.; Li, F. CXCL8 Antagonist Improves Diabetic Nephropathy in Male Mice With Diabetes and Attenuates High Glucose-Induced Mesangial Injury. Endocrinology 2017, 158, 1671-1684. [CrossRef]

44. Mohamed, R.; Jayakumar, C.; Chen, F.; Fulton, D.; Stepp, D.; Gansevoort, R.T.; Ramesh, G. Low-Dose IL-17 Therapy Prevents and Reverses Diabetic Nephropathy, Metabolic Syndrome, and Associated Organ Fibrosis. J. Am. Soc. Nephrol. 2016, 27, 745-765. [CrossRef] [PubMed]

45. Ma, J.; Li, Y.J.; Chen, X.; Kwan, T.; Chadban, S.J.; Wu, H. Interleukin 17A Promotes Diabetic Kidney Injury. Sci. Rep. 2019, 9, 2264. [CrossRef] [PubMed]

46. Okada, S.; Shikata, K.; Matsuda, M.; Ogawa, D.; Usui, H.; Kido, Y.; Nagase, R.; Wada, J.; Shikata, Y.; Makino, H. Intercellular Adhesion Molecule-1-Deficient Mice Are Resistant against Renal Injury after Induction of Diabetes. Diabetes 2003, 52, $2586-2593$. [CrossRef] [PubMed]

47. Talsma, D.T.; Katta, K.; Ettema, M.A.B.; Kel, B.; Kusche-Gullberg, M.; Daha, M.R.; Stegeman, C.A.; van den Born, J.; Wang, L. Endothelial Heparan Sulfate Deficiency Reduces Inflammation and Fibrosis in Murine Diabetic Nephropathy. Lab. Investig. 2018, 98, 427-438. [CrossRef] [PubMed]

48. Sun, H.; Tian, J.; Xian, W.; Xie, T.; Yang, X. Pentraxin-3 Attenuates Renal Damage in Diabetic Nephropathy by Promoting M2 Macrophage Differentiation. Inflammation 2015, 38, 1739-1747. [CrossRef] [PubMed]

49. Zheng, D.; Wang, Y.; Cao, Q.; Lee, V.W.S.; Zheng, G.; Sun, Y.; Tan, T.K.; Wang, Y.; Alexander, S.I.; Harris, D.C.H. Transfused Macrophages Ameliorate Pancreatic and Renal Injury in Murine Diabetes Mellitus. Nephron Exp. Nephrol. 2011, 118, e87-e99. [CrossRef]

50. Devaraj, S.; Tobias, P.; Kasinath, B.S.; Ramsamooj, R.; Afify, A.; Jialal, I. Knockout of Toll-like Receptor-2 Attenuates Both the Proinflammatory State of Diabetes and Incipient Diabetic Nephropathy. Arterioscler Thromb. Vasc Biol. 2011, 31, 1796-1804. [CrossRef]

51. Wang, X.; Yao, B.; Wang, Y.; Fan, X.; Wang, S.; Niu, A.; Yang, H.; Fogo, A.; Zhang, M.-Z.; Harris, R.C. Macrophage Cyclooxygenase2 Protects Against Development of Diabetic Nephropathy. Diabetes 2017, 66, 494-504. [CrossRef]

52. Tesch, G.H.; Pullen, N.; Jesson, M.I.; Schlerman, F.J.; Nikolic-Paterson, D.J. Combined Inhibition of CCR2 and ACE Provides Added Protection against Progression of Diabetic Nephropathy in Nos3-Deficient Mice. Am. J. Physiol. Renal. Physiol. 2019, 317, F1439-F1449. [CrossRef]

53. Sugimoto, H.; Shikata, K.; Hirata, K.; Akiyama, K.; Matsuda, M.; Kushiro, M.; Shikata, Y.; Miyatake, N.; Miyasaka, M.; Makino, H. Increased Expression of Intercellular Adhesion Molecule-1 (ICAM-1) in Diabetic Rat Glomeruli: Glomerular Hyperfiltration Is a Potential Mechanism of ICAM-1 Upregulation. Diabetes 1997, 46, 2075-2081. [CrossRef]

54. Zhang, X.-L.; Guo, Y.-F.; Song, Z.-X.; Zhou, M. Vitamin D Prevents Podocyte Injury via Regulation of Macrophage M1/M2 Phenotype in Diabetic Nephropathy Rats. Endocrinology 2014, 155, 4939-4950. [CrossRef] [PubMed]

55. Zhang, X.; Zhao, Y.; Zhu, X.; Guo, Y.; Yang, Y.; Jiang, Y.; Liu, B. Active Vitamin D Regulates Macrophage M1/M2 Phenotypes via the STAT-1-TREM-1 Pathway in Diabetic Nephropathy. J. Cell Physiol. 2019, 234, 6917-6926. [CrossRef] [PubMed]

56. Ndisang, J.F.; Jadhav, A. Hemin Therapy Improves Kidney Function in Male Streptozotocin-Induced Diabetic Rats: Role of the Heme Oxygenase/Atrial Natriuretic Peptide/Adiponectin Axis. Endocrinology 2014, 155, 215-229. [CrossRef]

57. Ninichuk, V.; Clauss, S.; Kulkarni, O.; Schmid, H.; Segerer, S.; Radomska, E.; Eulberg, D.; Buchner, K.; Selve, N.; Klussmann, S.; et al. Late Onset of Ccl2 Blockade with the Spiegelmer MNOX-E36-3'PEG Prevents Glomerulosclerosis and Improves Glomerular Filtration Rate in Db/Db Mice. Am. J. Pathol. 2008, 172, 628-637. [CrossRef]

58. Chow, F.Y.; Nikolic-Paterson, D.J.; Ozols, E.; Atkins, R.C.; Tesch, G.H. Intercellular Adhesion Molecule-1 Deficiency Is Protective against Nephropathy in Type 2 Diabetic Db/Db Mice. J. Am. Soc. Nephrol. 2005, 16, 1711-1722. [CrossRef] 
59. Yang, S.; Ma, C.; Wu, H.; Zhang, H.; Yuan, F.; Yang, G.; Yang, Q.; Jia, L.; Liang, Z.; Kang, L. Tectorigenin Attenuates Diabetic Nephropathy by Improving Vascular Endothelium Dysfunction through Activating AdipoR1/2 Pathway. Pharmacol. Res. 2020, 153, 104678. [CrossRef] [PubMed]

60. Lim, A.K.H.; Ma, F.Y.; Nikolic-Paterson, D.J.; Thomas, M.C.; Hurst, L.A.; Tesch, G.H. Antibody Blockade of C-Fms Suppresses the Progression of Inflammation and Injury in Early Diabetic Nephropathy in Obese Db/Db Mice. Diabetologia 2009, 52, $1669-1679$. [CrossRef]

61. Ndisang, J.F.; Jadhav, A.; Mishra, M. The Heme Oxygenase System Suppresses Perirenal Visceral Adiposity, Abates Renal Inflammation and Ameliorates Diabetic Nephropathy in Zucker Diabetic Fatty Rats. PLoS ONE 2014, 9, e87936. [CrossRef]

62. Nourshargh, S.; Alon, R. Leukocyte Migration into Inflamed Tissues. Immunity 2014, 41, 694-707. [CrossRef]

63. Karimi, Z.; Kahe, F.; Jamil, A.; Marszalek, J.; Ghanbari, A.; Afarideh, M.; Khajeh, E.; Noshad, S.; Esteghamati, A.; Chi, G. Intercellular Adhesion Molecule-1 in Diabetic Patients with and without Microalbuminuria. Diabetes Metab Syndr. 2018, 12, 365-368. [CrossRef]

64. Coimbra, T.M.; Janssen, U.; Gröne, H.J.; Ostendorf, T.; Kunter, U.; Schmidt, H.; Brabant, G.; Floege, J. Early Events Leading to Renal Injury in Obese Zucker (Fatty) Rats with Type II Diabetes. Kidney Int. 2000, 57, 167-182. [CrossRef] [PubMed]

65. Guillén-Gómez, E.; Bardají-de-Quixano, B.; Ferrer, S.; Brotons, C.; Knepper, M.A.; Carrascal, M.; Abian, J.; Mas, J.M.; Calero, F.; Ballarín, J.A.; et al. Urinary Proteome Analysis Identified Neprilysin and VCAM as Proteins Involved in Diabetic Nephropathy. J. Diabetes Res. 2018, 2018, 6165303. [CrossRef] [PubMed]

66. Hirata, K.; Shikata, K.; Matsuda, M.; Akiyama, K.; Sugimoto, H.; Kushiro, M.; Makino, H. Increased Expression of Selectins in Kidneys of Patients with Diabetic Nephropathy. Diabetologia 1998, 41, 185-192. [CrossRef] [PubMed]

67. Deshmane, S.L.; Kremlev, S.; Amini, S.; Sawaya, B.E. Monocyte Chemoattractant Protein-1 (MCP-1): An Overview. J. Interferon Cytokine Res. 2009, 29, 313-326. [CrossRef] [PubMed]

68. Mezzano, S.A.; Barría, M.; Droguett, M.A.; Burgos, M.E.; Ardiles, L.G.; Flores, C.; Egido, J. Tubular NF-KappaB and AP-1 Activation in Human Proteinuric Renal Disease. Kidney Int. 2001, 60, 1366-1377. [CrossRef]

69. Donadelli, R.; Abbate, M.; Zanchi, C.; Corna, D.; Tomasoni, S.; Benigni, A.; Remuzzi, G.; Zoja, C. Protein Traffic Activates NF-KB Gene Signaling and Promotes MCP-1-Dependent Interstitial Inflammation. Am. J. Kidney Dis. 2000, 36, 1226-1241. [CrossRef]

70. Banba, N.; Nakamura, T.; Matsumura, M.; Kuroda, H.; Hattori, Y.; Kasai, K. Possible Relationship of Monocyte Chemoattractant Protein-1 with Diabetic Nephropathy. Kidney Int. 2000, 58, 684-690. [CrossRef]

71. Saitoh, A.; Sekizuka, K.; Hayashi, T.; Kaneko, S.; Suzuki, Y.; Tomino, Y. Detection of Urinary MCP-1 in Patients with Diabetic Nephropathy. Nephron 1998, 80, 99. [CrossRef]

72. Tashiro, K.; Koyanagi, I.; Saitoh, A.; Shimizu, A.; Shike, T.; Ishiguro, C.; Koizumi, M.; Funabiki, K.; Horikoshi, S.; Shirato, I.; et al. Urinary Levels of Monocyte Chemoattractant Protein-1 (MCP-1) and Interleukin-8 (IL-8), and Renal Injuries in Patients with Type 2 Diabetic Nephropathy. J. Clin. Lab. Anal. 2002, 16, 1-4. [CrossRef] [PubMed]

73. Wada, T.; Furuichi, K.; Sakai, N.; Iwata, Y.; Yoshimoto, K.; Shimizu, M.; Takeda, S.I.; Takasawa, K.; Yoshimura, M.; Kida, H.; et al Up-Regulation of Monocyte Chemoattractant Protein-1 in Tubulointerstitial Lesions of Human Diabetic Nephropathy. Kidney Int. 2000, 58, 1492-1499. [CrossRef] [PubMed]

74. Susztak, K.; Böttinger, E.; Novetsky, A.; Liang, D.; Zhu, Y.; Ciccone, E.; Wu, D.; Dunn, S.; McCue, P.; Sharma, K. Molecular Profiling of Diabetic Mouse Kidney Reveals Novel Genes Linked to Glomerular Disease. Diabetes 2004, 53, 784-794. [CrossRef] [PubMed]

75. Li, C.; Yang, C.W.; Park, C.W.; Ahn, H.J.; Kim, W.Y.; Yoon, K.H.; Suh, S.H.; Lim, S.W.; Cha, J.H.; Kim, Y.S.; et al. Long-Term Treatment with Ramipril Attenuates Renal Osteopontin Expression in Diabetic Rats. Kidney Int. 2003, 63, 454-463. [CrossRef] [PubMed]

76. Weber, G.F.; Ashkar, S.; Glimcher, M.J.; Cantor, H. Receptor-Ligand Interaction between CD44 and Osteopontin (Eta-1). Science 1996, 271, 509-512. [CrossRef] [PubMed]

77. Sodhi, C.P.; Batlle, D.; Sahai, A. Osteopontin Mediates Hypoxia-Induced Proliferation of Cultured Mesangial Cells: Role of PKC and P38 MAPK. Kidney Int. 2000, 58, 691-700. [CrossRef] [PubMed]

78. Endlich, N.; Sunohara, M.; Nietfeld, W.; Wolski, E.W.; Schiwek, D.; Kränzlin, B.; Gretz, N.; Kriz, W.; Eickhoff, H.; Endlich, K. Analysis of Differential Gene Expression in Stretched Podocytes: Osteopontin Enhances Adaptation of Podocytes to Mechanical Stress. FASEB J. 2002, 16, 1850-1852. [CrossRef]

79. Grutzmacher, C.; Park, S.; Zhao, Y.; Morrison, M.E.; Sheibani, N.; Sorenson, C.M. Aberrant Production of Extracellular Matrix Proteins and Dysfunction in Kidney Endothelial Cells with a Short Duration of Diabetes. Am. J. Physiol. Renal. Physiol. 2013, 304, F19-F30. [CrossRef]

80. Kelly, D.J.; Wilkinson-Berka, J.L.; Ricardo, S.D.; Cox, A.J.; Gilbert, R.E. Progression of Tubulointerstitial Injury by OsteopontinInduced Macrophage Recruitment in Advanced Diabetic Nephropathy of Transgenic (MRen-2)27 Rats. Nephrol. Dial. Transplant. 2002, 17, 985-991. [CrossRef]

81. Kelly, D.J.; Chanty, A.; Gow, R.M.; Zhang, Y.; Gilbert, R.E. Protein Kinase Cbeta Inhibition Attenuates Osteopontin Expression, Macrophage Recruitment, and Tubulointerstitial Injury in Advanced Experimental Diabetic Nephropathy. J. Am. Soc. Nephrol 2005, 16, 1654-1660. [CrossRef]

82. Nicholas, S.B.; Liu, J.; Kim, J.; Ren, Y.; Collins, A.R.; Nguyen, L.; Hsueh, W.A. Critical Role for Osteopontin in Diabetic Nephropathy. Kidney Int. 2010, 77, 588-600. [CrossRef] 
83. Lin, M.; Yiu, W.H.; Li, R.X.; Wu, H.J.; Wong, D.W.L.; Chan, L.Y.Y.; Leung, J.C.K.; Lai, K.N.; Tang, S.C.W. The TLR4 Antagonist CRX-526 Protects against Advanced Diabetic Nephropathy. Kidney Int. 2013, 83, 887-900. [CrossRef] [PubMed]

84. Junaid, A.; Amara, F.M. Osteopontin: Correlation with Interstitial Fibrosis in Human Diabetic Kidney and PI3-Kinase-Mediated Enhancement of Expression by Glucose in Human Proximal Tubular Epithelial Cells. Histopathology 2004, 44, 136-146. [CrossRef]

85. Kikuchi, Y.; Ikee, R.; Hemmi, N.; Hyodo, N.; Saigusa, T.; Namikoshi, T.; Yamada, M.; Suzuki, S.; Miura, S. Fractalkine and Its Receptor, CX3CR1, Upregulation in Streptozotocin-Induced Diabetic Kidneys. Nephron Exp. Nephrol. 2004, 97, e17-e25. [CrossRef] [PubMed]

86. Wang, Y.; Wei, Q.; Liu, Q.; Li, Z.; Zhou, L.; Zou, F.; Yuan, Y.; Sun, Z. Crosstalk between Monocytes and Renal Mesangial Cells via Interaction of Metalloproteinases and Fractalkine in Diabetic Nephropathy. Mol. Med. Rep. 2013, 8, 1817-1823. [CrossRef]

87. Mosser, D.M. The Many Faces of Macrophage Activation. J. Leukoc Biol 2003, 73, 209-212. [CrossRef] [PubMed]

88. Chinetti-Gbaguidi, G.; Colin, S.; Staels, B. Macrophage Subsets in Atherosclerosis. Nat. Rev. Cardiol. 2015, 12, 10-17. [CrossRef]

89. Murray, P.J.; Allen, J.E.; Biswas, S.K.; Fisher, E.A.; Gilroy, D.W.; Goerdt, S.; Gordon, S.; Hamilton, J.A.; Ivashkiv, L.B.; Lawrence, T.; et al. Macrophage Activation and Polarization: Nomenclature and Experimental Guidelines. Immunity 2014, 41, 14-20. [CrossRef] [PubMed]

90. Kodelja, V.; Müller, C.; Politz, O.; Hakij, N.; Orfanos, C.E.; Goerdt, S. Alternative Macrophage Activation-Associated CCChemokine-1, a Novel Structural Homologue of Macrophage Inflammatory Protein-1 Alpha with a Th2-Associated Expression Pattern. J. Immunol. 1998, 160, 1411-1418. [PubMed]

91. Arora, S.; Dev, K.; Agarwal, B.; Das, P.; Syed, M.A. Macrophages: Their Role, Activation and Polarization in Pulmonary Diseases. Immunobiology 2018, 223, 383-396. [CrossRef] [PubMed]

92. Kobori, H.; Nangaku, M.; Navar, L.G.; Nishiyama, A. The Intrarenal Renin-Angiotensin System: From Physiology to the Pathobiology of Hypertension and Kidney Disease. Pharmacol. Rev. 2007, 59, 251-287. [CrossRef] [PubMed]

93. Nguyen, G.; Muller, D.N. The Biology of the (pro)Renin Receptor. J. Am. Soc. Nephrol. 2010, 21, 18-23. [CrossRef] [PubMed]

94. Rice, G.I.; Thomas, D.A.; Grant, P.J.; Turner, A.J.; Hooper, N.M. Evaluation of Angiotensin-Converting Enzyme (ACE), Its Homologue ACE2 and Neprilysin in Angiotensin Peptide Metabolism. Biochem. J. 2004, 383, 45-51. [CrossRef] [PubMed]

95. Flores-Muñoz, M.; Smith, N.J.; Haggerty, C.; Milligan, G.; Nicklin, S.A. Angiotensin1-9 Antagonises pro-Hypertrophic Signalling in Cardiomyocytes via the Angiotensin Type 2 Receptor. J. Physiol. 2011, 589, 939-951. [CrossRef] [PubMed]

96. Brem, A.S.; Morris, D.J.; Gong, R. Aldosterone-Induced Fibrosis in the Kidney: Questions and Controversies. Am. J. Kidney Dis. 2011, 58, 471-479. [CrossRef] [PubMed]

97. Kelly, D.J.; Zhang, Y.; Moe, G.; Naik, G.; Gilbert, R.E. Aliskiren, a Novel Renin Inhibitor, Is Renoprotective in a Model of Advanced Diabetic Nephropathy in Rats. Diabetologia 2007, 50, 2398-2404. [CrossRef]

98. Epstein, M.; Williams, G.H.; Weinberger, M.; Lewin, A.; Krause, S.; Mukherjee, R.; Patni, R.; Beckerman, B. Selective Aldosterone Blockade with Eplerenone Reduces Albuminuria in Patients with Type 2 Diabetes. Clin. J. Am. Soc. Nephrol. 2006, 1, 940-951. [CrossRef]

99. Lytvyn, Y.; Godoy, L.C.; Scholtes, R.A.; van Raalte, D.H.; Cherney, D.Z. Mineralocorticoid Antagonism and Diabetic Kidney Disease. Curr. Diab. Rep. 2019, 19, 4. [CrossRef]

100. Malek, V.; Sharma, N.; Sankrityayan, H.; Gaikwad, A.B. Concurrent Neprilysin Inhibition and Renin-Angiotensin System Modulations Prevented Diabetic Nephropathy. Life Sci. 2019, 221, 159-167. [CrossRef] [PubMed]

101. Burns, K.D. Angiotensin II and Its Receptors in the Diabetic Kidney. Am. J. Kidney Dis. 2000, 36, 449-467. [CrossRef] [PubMed]

102. Price, D.A.; Porter, L.E.; Gordon, M.; Fisher, N.D.; De'Oliveira, J.M.; Laffel, L.M.; Passan, D.R.; Williams, G.H.; Hollenberg, N.K. The Paradox of the Low-Renin State in Diabetic Nephropathy. J. Am. Soc. Nephrol. 1999, 10, 2382-2391. [CrossRef]

103. Konoshita, T.; Wakahara, S.; Mizuno, S.; Motomura, M.; Aoyama, C.; Makino, Y.; Kawai, Y.; Kato, N.; Koni, I.; Miyamori, I.; et al. Tissue Gene Expression of Renin-Angiotensin System in Human Type 2 Diabetic Nephropathy. Diabetes Care 2006, $29,848-852$. [CrossRef] [PubMed]

104. Lewis, E.J.; Hunsicker, L.G.; Clarke, W.R.; Berl, T.; Pohl, M.A.; Lewis, J.B.; Ritz, E.; Atkins, R.C.; Rohde, R.; Raz, I.; et al. Renoprotective Effect of the Angiotensin-Receptor Antagonist Irbesartan in Patients with Nephropathy Due to Type 2 Diabetes. N. Engl. J. Med. 2001, 345, 851-860. [CrossRef] [PubMed]

105. Brenner, B.M.; Cooper, M.E.; de Zeeuw, D.; Keane, W.F.; Mitch, W.E.; Parving, H.H.; Remuzzi, G.; Snapinn, S.M.; Zhang, Z.; Shahinfar, S.; et al. Effects of Losartan on Renal and Cardiovascular Outcomes in Patients with Type 2 Diabetes and Nephropathy. N. Engl. J. Med. 2001, 345, 861-869. [CrossRef]

106. The GISEN Group (Gruppo Italiano Di Studi Epidemiologici in Nefrologia). Randomised Placebo-Controlled Trial of Effect of Ramipril on Decline in Glomerular Filtration Rate and Risk of Terminal Renal Failure in Proteinuric, Non-Diabetic Nephropathy. Lancet 1997, 349, 1857-1863.

107. Barnett, A.H.; Bain, S.C.; Bouter, P.; Karlberg, B.; Madsbad, S.; Jervell, J.; Mustonen, J.; Diabetics Exposed to Telmisartan and Enalapril Study Group. Angiotensin-Receptor Blockade versus Converting-Enzyme Inhibition in Type 2 Diabetes and Nephropathy. N. Engl. J. Med. 2004, 351, 1952-1961. [CrossRef]

108. de Zeeuw, D.; Remuzzi, G.; Parving, H.-H.; Keane, W.F.; Zhang, Z.; Shahinfar, S.; Snapinn, S.; Cooper, M.E.; Mitch, W.E.; Brenner, B.M. Proteinuria, a Target for Renoprotection in Patients with Type 2 Diabetic Nephropathy: Lessons from RENAAL. Kidney Int. 2004, 65, 2309-2320. [CrossRef] 
109. Bakris, G.L.; Agarwal, R.; Anker, S.D.; Pitt, B.; Ruilope, L.M.; Rossing, P.; Kolkhof, P.; Nowack, C.; Schloemer, P.; Joseph, A.; et al. Effect of Finerenone on Chronic Kidney Disease Outcomes in Type 2 Diabetes. N. Engl. J. Med. 2020, 383, 2219-2229. [CrossRef]

110. Parving, H.-H.; Persson, F.; Lewis, J.B.; Lewis, E.J.; Hollenberg, N.K.; AVOID Study Investigators. Aliskiren Combined with Losartan in Type 2 Diabetes and Nephropathy. N. Engl. J. Med. 2008, 358, 2433-2446. [CrossRef]

111. Fried, L.F.; Emanuele, N.; Zhang, J.H.; Brophy, M.; Conner, T.A.; Duckworth, W.; Leehey, D.J.; McCullough, P.A.; O'Connor, T.; Palevsky, P.M.; et al. Combined Angiotensin Inhibition for the Treatment of Diabetic Nephropathy. N. Engl. J. Med. 2013, 369, 1892-1903. [CrossRef]

112. Hilgers, K.F. Monocytes/Macrophages in Hypertension. J. Hypertens 2002, 20, 593-596. [CrossRef]

113. Keidar, S.; Strizevsky, A.; Raz, A.; Gamliel-Lazarovich, A. ACE2 Activity Is Increased in Monocyte-Derived Macrophages from Prehypertensive Subjects. Nephrol Dial. Transplant. 2007, 22, 597-601. [CrossRef] [PubMed]

114. Yanagitani, Y.; Rakugi, H.; Okamura, A.; Moriguchi, K.; Takiuchi, S.; Ohishi, M.; Suzuki, K.; Higaki, J.; Ogihara, T. Angiotensin II Type 1 Receptor-Mediated Peroxide Production in Human Macrophages. Hypertension 1999, 33, 335-339. [CrossRef] [PubMed]

115. Okamura, A.; Rakugi, H.; Ohishi, M.; Yanagitani, Y.; Takiuchi, S.; Moriguchi, K.; Fennessy, P.A.; Higaki, J.; Ogihara, T. Upregulation of Renin-Angiotensin System during Differentiation of Monocytes to Macrophages. J. Hypertens 1999, 17, 537-545. [CrossRef]

116. Skiba, D.S.; Nosalski, R.; Mikolajczyk, T.P.; Siedlinski, M.; Rios, F.J.; Montezano, A.C.; Jawien, J.; Olszanecki, R.; Korbut, R.; Czesnikiewicz-Guzik, M.; et al. Anti-Atherosclerotic Effect of the Angiotensin 1-7 Mimetic AVE0991 Is Mediated by Inhibition of Perivascular and Plaque Inflammation in Early Atherosclerosis. Br. J. Pharmacol. 2017, 174, 4055-4069. [CrossRef] [PubMed]

117. van der Heijden, C.D.C.C.; Deinum, J.; Joosten, L.A.B.; Netea, M.G.; Riksen, N.P. The Mineralocorticoid Receptor as a Modulator of Innate Immunity and Atherosclerosis. Cardiovasc Res. 2018, 114, 944-953. [CrossRef]

118. Daugherty, A.; Rateri, D.L.; Lu, H.; Inagami, T.; Cassis, L.A. Hypercholesterolemia Stimulates Angiotensin Peptide Synthesis and Contributes to Atherosclerosis through the AT1A Receptor. Circulation 2004, 110, 3849-3857. [CrossRef] [PubMed]

119. Narumi, K.; Hirose, T.; Sato, E.; Mori, T.; Kisu, K.; Ishikawa, M.; Totsune, K.; Ishii, T.; Ichihara, A.; Nguyen, G.; et al. A Functional (pro)Renin Receptor Is Expressed in Human Lymphocytes and Monocytes. Am. J. Physiol. Renal. Physiol. 2015, 308, F487-F499. [CrossRef] [PubMed]

120. Feldt, S.; Batenburg, W.W.; Mazak, I.; Maschke, U.; Wellner, M.; Kvakan, H.; Dechend, R.; Fiebeler, A.; Burckle, C.; Contrepas, A.; et al. Prorenin and Renin-Induced Extracellular Signal-Regulated Kinase 1/2 Activation in Monocytes Is Not Blocked by Aliskiren or the Handle-Region Peptide. Hypertension 2008, 51, 682-688. [CrossRef]

121. Nahmod, K.A.; Vermeulen, M.E.; Raiden, S.; Salamone, G.; Gamberale, R.; Fernández-Calotti, P.; Alvarez, A.; Nahmod, V.; Giordano, M.; Geffner, J.R. Control of Dendritic Cell Differentiation by Angiotensin II. FASEB J. 2003, 17, 491-493. [CrossRef]

122. Viinikainen, A.; Nyman, T.; Fyhrquist, F.; Saijonmaa, O. Downregulation of Angiotensin Converting Enzyme by TNF-Alpha in Differentiating Human Macrophages. Cytokine 2002, 18, 304-310. [CrossRef] [PubMed]

123. Merino, A.; Alvarez-Lara, M.A.; Ramirez, R.; Carracedo, J.; Martin-Malo, A.; Aljama, P. Losartan Prevents the Development of the Pro-Inflammatory Monocytes CD14+CD16+ in Haemodialysis Patients. Nephrol. Dial. Transplant. 2012, 27, 2907-2912. [CrossRef]

124. Hermansson, C.; Lundqvist, A.; Magnusson, L.U.; Ullström, C.; Bergström, G.; Hultén, L.M. Macrophage CD14 Expression in Human Carotid Plaques Is Associated with Complicated Lesions, Correlates with Thrombosis, and Is Reduced by Angiotensin Receptor Blocker Treatment. Int. Immunopharmaco.l 2014, 22, 318-323. [CrossRef]

125. Zhou, S.; Lu, H.; Chen, R.; Tian, Y.; Jiang, Y.; Zhang, S.; Ni, D.; Su, Z.; Shao, X. Angiotensin II Enhances the Acetylation and Release of HMGB1 in RAW264.7 Macrophage. Cell Biol. Int. 2018, 42, 1160-1169. [CrossRef] [PubMed]

126. Wu, L.; Chen, K.; Xiao, J.; Xin, J.; Zhang, L.; Li, X.; Li, L.; Si, J.; Wang, L.; Ma, K. Angiotensin II Induces RAW264.7 Macrophage Polarization to the M1-type through the Connexin 43/NF-kB Pathway. Mol. Med. Rep. 2020, 21, 2103-2112. [CrossRef]

127. Hammer, A.; Yang, G.; Friedrich, J.; Kovacs, A.; Lee, D.-H.; Grave, K.; Jörg, S.; Alenina, N.; Grosch, J.; Winkler, J.; et al. Role of the Receptor Mas in Macrophage-Mediated Inflammation in Vivo. Proc. Natl. Acad. Sci. USA 2016, 113, 14109-14114. [CrossRef] [PubMed]

128. De Carvalho Santuchi, M.; Dutra, M.F.; Vago, J.P.; Lima, K.M.; Galvão, I.; de Souza-Neto, F.P.; Morais, E.; Silva, M.; Oliveira, A.C.; de Oliveira, F.C.B.; et al. Angiotensin-(1-7) and Alamandine Promote Anti-Inflammatory Response in Macrophages In Vitro and In Vivo. Mediators Inflamm. 2019, 2019, 2401081. [CrossRef]

129. Souza, L.L.; Costa-Neto, C.M. Angiotensin-(1-7) Decreases LPS-Induced Inflammatory Response in Macrophages. J. Cell Physiol. 2012, 227, 2117-2122. [CrossRef] [PubMed]

130. Jiang, M.; Huang, W.; Wang, Z.; Ren, F.; Luo, L.; Zhou, J.; Yan, R.; Xia, N.; Tang, L. Anti-Inflammatory Effects of Ang-(1-7) via TLR4-Mediated Inhibition of the JNK/FoxO1 Pathway in Lipopolysaccharide-Stimulated RAW264.7 cells. Dev. Comp. Immunol. 2019, 92, 291-298. [CrossRef] [PubMed]

131. Guo, Y.-J.; Li, W.-H.; Wu, R.; Xie, Q.; Cui, L.-Q. ACE2 Overexpression Inhibits Angiotensin II-Induced Monocyte Chemoattractant Protein-1 Expression in Macrophages. Arch. Med. Res. 2008, 39, 149-154. [CrossRef]

132. Urushihara, M.; Kondo, S.; Kinoshita, Y.; Ozaki, N.; Jamba, A.; Nagai, T.; Fujioka, K.; Hattori, T.; Kagami, S. (Pro)Renin Receptor Promotes Crescent Formation via the ERK1/2 and Wnt/ $\beta$-Catenin Pathways in Glomerulonephritis. Am. J. Physiol. Renal. Physiol. 2020, 319, F571-F578. [CrossRef]

133. Yoshida, A.; Kanamori, H.; Naruse, G.; Minatoguchi, S.; Iwasa, M.; Yamada, Y.; Mikami, A.; Kawasaki, M.; Nishigaki, K.; Minatoguchi, S. (Pro)Renin Receptor Blockade Ameliorates Heart Failure Caused by Chronic Kidney Disease. J. Card Fail. 2019, 25, 286-300. [CrossRef] 
134. Hahn, A.W.; Jonas, U.; Bühler, F.R.; Resink, T.J. Activation of Human Peripheral Monocytes by Angiotensin II. FEBS Lett. 1994, 347, 178-180. [CrossRef]

135. Alvarez, A.; Cerdá-Nicolás, M.; Naim Abu Nabah, Y.; Mata, M.; Issekutz, A.C.; Panés, J.; Lobb, R.R.; Sanz, M.-J. Direct Evidence of Leukocyte Adhesion in Arterioles by Angiotensin II. Blood 2004, 104, 402-408. [CrossRef] [PubMed]

136. Tummala, P.E.; Chen, X.L.; Sundell, C.L.; Laursen, J.B.; Hammes, C.P.; Alexander, R.W.; Harrison, D.G.; Medford, R.M. Angiotensin II Induces Vascular Cell Adhesion Molecule-1 Expression in Rat Vasculature: A Potential Link between the Renin-Angiotensin System and Atherosclerosis. Circulation 1999, 100, 1223-1229. [CrossRef]

137. Lin, Q.-Y.; Lang, P.-P.; Zhang, Y.-L.; Yang, X.-L.; Xia, Y.-L.; Bai, J.; Li, H.-H. Pharmacological Blockage of ICAM-1 Improves Angiotensin II-Induced Cardiac Remodeling by Inhibiting Adhesion of LFA-1+ Monocytes. Am. J. Physiol. Heart Circ. Physiol. 2019, 317, H1301-H1311. [CrossRef] [PubMed]

138. Kamal, F.; Yanakieva-Georgieva, N.; Piao, H.; Morioka, T.; Oite, T. Local Delivery of Angiotensin II Receptor Blockers into the Kidney Passively Attenuates Inflammatory Reactions during the Early Phases of Streptozotocin-Induced Diabetic Nephropathy through Inhibition of Calpain Activity. Nephron. Exp. Nephrol. 2010, 115, e69-e79. [CrossRef] [PubMed]

139. Kato, S.; Luyckx, V.A.; Ots, M.; Lee, K.W.; Ziai, F.; Troy, J.L.; Brenner, B.M.; MacKenzie, H.S. Renin-Angiotensin Blockade Lowers MCP-1 Expression in Diabetic Rats. Kidney Int. 1999, 56, 1037-1048. [CrossRef] [PubMed]

140. Wiggins, K.J.; Tiauw, V.; Zhang, Y.; Gilbert, R.E.; Langham, R.G.; Kelly, D.J. Perindopril Attenuates Tubular Hypoxia and Inflammation in an Experimental Model of Diabetic Nephropathy in Transgenic Ren-2 Rats. Nephrology (Carlton) 2008, 13, 721-729. [CrossRef] [PubMed]

141. Zhang, M.-Z.; Wang, S.; Yang, S.; Yang, H.; Fan, X.; Takahashi, T.; Harris, R.C. Role of Blood Pressure and the Renin-Angiotensin System in Development of Diabetic Nephropathy (DN) in ENOS-/- Db/Db Mice. Am. J. Physiol. Renal. Physiol. 2012, 302, F433-F438. [CrossRef]

142. Ding, D.; Du, Y.; Qiu, Z.; Yan, S.; Chen, F.; Wang, M.; Yang, S.; Zhou, Y.; Hu, X.; Deng, Y.; et al. Vaccination against Type 1 Angiotensin Receptor Prevents Streptozotocin-Induced Diabetic Nephropathy. J. Mol. Med. (Berl.) 2016, 94, 207-218. [CrossRef] [PubMed]

143. Cassis, P.; Locatelli, M.; Corna, D.; Villa, S.; Rottoli, D.; Cerullo, D.; Abbate, M.; Remuzzi, G.; Benigni, A.; Zoja, C. Addition of Cyclic Angiotensin-(1-7) to Angiotensin-Converting Enzyme Inhibitor Therapy Has a Positive Add-on Effect in Experimental Diabetic Nephropathy. Kidney Int. 2019, 96, 906-917. [CrossRef] [PubMed]

144. Cucak, H.; Nielsen Fink, L.; Højgaard Pedersen, M.; Rosendahl, A. Enalapril Treatment Increases T Cell Number and Promotes Polarization towards M1-like Macrophages Locally in Diabetic Nephropathy. Int. Immunopharmacol 2015, 25, 30-42. [CrossRef] [PubMed]

145. Wu, Y.-G.; Lin, H.; Qian, H.; Zhao, M.; Qi, X.-M.; Wu, G.-Z.; Lin, S.-T. Renoprotective Effects of Combination of Angiotensin Converting Enzyme Inhibitor with Mycophenolate Mofetil in Diabetic Rats. Inflamm. Res. 2006, 55, 192-199. [CrossRef] [PubMed]

146. Zhou, G.; Johansson, U.; Peng, X.-R.; Bamberg, K.; Huang, Y. An Additive Effect of Eplerenone to ACE Inhibitor on Slowing the Progression of Diabetic Nephropathy in the Db/Db Mice. Am. J. Transl. Res. 2016, 8, 1339-1354.

147. Greene, E.L.; Kren, S.; Hostetter, T.H. Role of Aldosterone in the Remnant Kidney Model in the Rat. J. Clin. Investig. 1996, 98, 1063-1068. [CrossRef] [PubMed]

148. Nistala, R.; Meuth, A.; Smith, C.; Annayya, A. Reliable and High Efficiency Extraction of Kidney Immune Cells. J. Vis. Exp. 2016. [CrossRef]

149. Ma, L.-J.; Corsa, B.A.; Zhou, J.; Yang, H.; Li, H.; Tang, Y.-W.; Babaev, V.R.; Major, A.S.; Linton, M.F.; Fazio, S.; et al. Angiotensin Type 1 Receptor Modulates Macrophage Polarization and Renal Injury in Obesity. Am. J. Physiol. Renal. Physiol. 2011, 300, F1203-F1213. [CrossRef]

150. Yamamoto, S.; Yancey, P.G.; Zuo, Y.; Ma, L.-J.; Kaseda, R.; Fogo, A.B.; Ichikawa, I.; Linton, M.F.; Fazio, S.; Kon, V. Macrophage Polarization by Angiotensin II-Type 1 Receptor Aggravates Renal Injury-Acceleration of Atherosclerosis. Arterioscler. Thromb Vasc. Biol. 2011, 31, 2856-2864. [CrossRef]

151. Marketou, M.E.; Kontaraki, J.E.; Tsakountakis, N.A.; Zacharis, E.A.; Kochiadakis, G.E.; Arfanakis, D.A.; Parthenakis, F.; Chlouverakis, G.; Vardas, P.E. Differential Effect of Telmisartan and Amlodipine on Monocyte Chemoattractant Protein-1 and Peroxisome Proliferator-Activated Receptor-Gamma Gene Expression in Peripheral Monocytes in Patients with Essential Hypertension. Am. J. Cardiol. 2011, 107, 59-63. [CrossRef] [PubMed]

152. Fujisaka, S.; Usui, I.; Kanatani, Y.; Ikutani, M.; Takasaki, I.; Tsuneyama, K.; Tabuchi, Y.; Bukhari, A.; Yamazaki, Y.; Suzuki, H.; et al. Telmisartan Improves Insulin Resistance and Modulates Adipose Tissue Macrophage Polarization in High-Fat-Fed Mice. Endocrinology 2011, 152, 1789-1799. [CrossRef] [PubMed]

153. Bakris, G.; Burgess, E.; Weir, M.; Davidai, G.; Koval, S.; AMADEO Study Investigators. Telmisartan Is More Effective than Losartan in Reducing Proteinuria in Patients with Diabetic Nephropathy. Kidney Int. 2008, 74, 364-369. [CrossRef] [PubMed]

154. Rayego-Mateos, S.; Morgado-Pascual, J.L.; Opazo-Ríos, L.; Guerrero-Hue, M.; García-Caballero, C.; Vázquez-Carballo, C.; Mas, S.; Sanz, A.B.; Herencia, C.; Mezzano, S.; et al. Pathogenic Pathways and Therapeutic Approaches Targeting Inflammation in Diabetic Nephropathy. Int. J. Mol. Sci. 2020, 21, 3798. [CrossRef] 